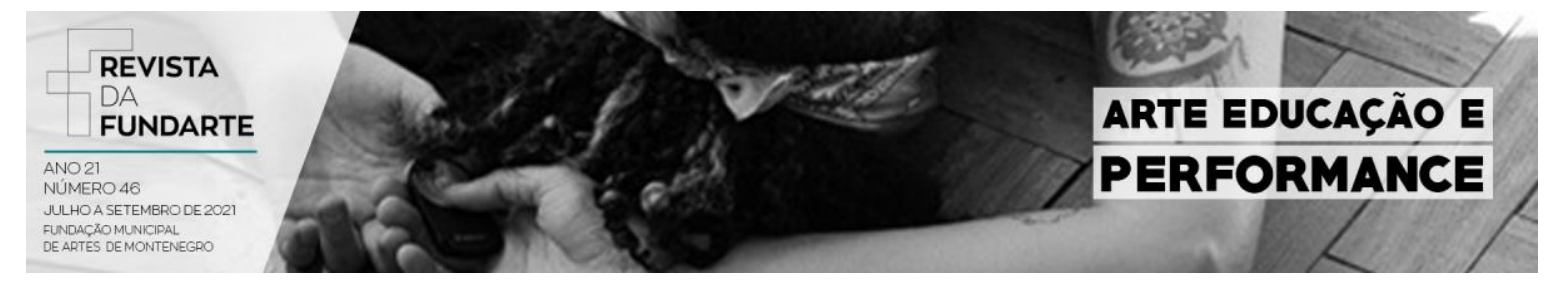

\title{
AS INFLUÊNCIAS DA ARTE ABSTRATA NOS JOGOS DE TABULEIROS MODERNOS
}

\author{
Raphael de Alcântara do Carmo
}

José Maximiano Arruda Ximenes de Lima

DOI: http://dx.doi.org/10.19179\%2F2319-0868.823

CARMO, Raphael de Alcântara do; LIMA, José Maximiano Arruda Ximenes de. As influências da arte abstrata nos jogos de tabuleiros modernos. Revista da FUNDARTE. Montenegro, p.01-27, ano 21, nํㅜ 46, setembro de 2021.

Disponível em: http://seer.fundarte.rs.gov.br/index.php/RevistadaFundarte/issue/archive > 30 de setembro de 2021. 


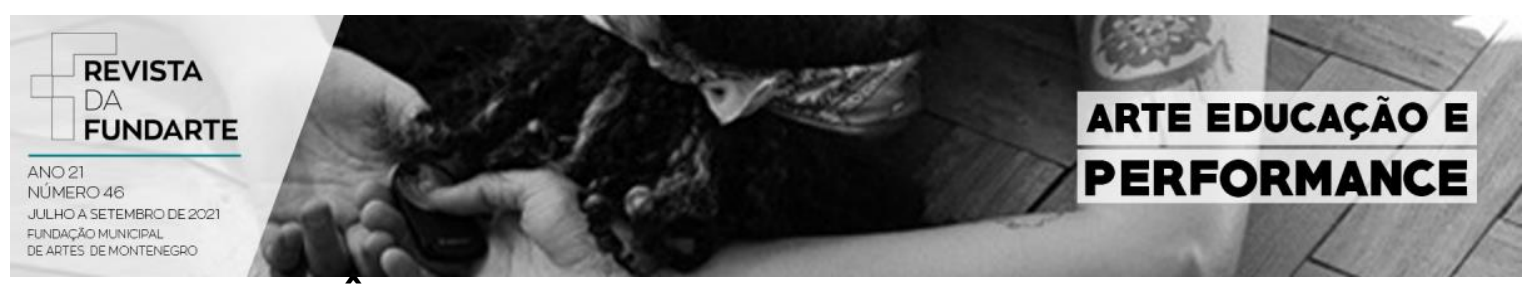

\title{
AS INFLUÊNCIAS DA ARTE ABSTRATA NOS JOGOS DE TABULEIROS MODERNOS
}

\author{
Raphael de Alcântara do Carmo' \\ José Maximiano Arruda Ximenes de Lima²
}

\begin{abstract}
Resumo: Este artigo estabelece relações entre a Arte Abstrata e o jogo de tabuleiro moderno com base nos estudos de Kandinsky (2000) e Woods (2012). Assim, levantamos o seguinte questionamento: que influências da Arte Abstrata são incorporadas nas mecânicas dos jogos de tabuleiros modernos? Os dados foram coletados por meio de pesquisa bibliográfica e análises de jogos de tabuleiro. Os resultados obtidos demonstram como o Abstracionismo serve de inspiração para as iconografias dos jogos e também como o processo artístico é representado dentro dessas mecânicas. Apesar disso, dentre os jogos analisados, nenhum se propõe a falar sobre Arte Abstrata especificamente, utilizando obras de arte como componentes de jogo, mas sem se aprofundar na temática.
\end{abstract}

Palavras-chave: Arte Abstrata; Jogos de tabuleiro; Representação.

\section{THE INFLUENCES OF ABSTRACT ART IN MODERN BOARD GAMES}

\begin{abstract}
This article establishes relationships between Abstract Art and the modern board game based on the studies by Kandinsky (2000) and Woods (2012). Thus, we raise the following question: what influences of Abstract art are incorporated into the mechanics of modern board games? The data was collected through bibliographic research and analysis of board games. The results obtained demonstrate how the Abstract art serves as inspiration for the games iconographies and also how the artistic process is represented within these mechanics. Nevertheless, among the analyzed games,
\end{abstract}

\footnotetext{
${ }^{1}$ Mestrando no PPGArtes - IFCE, possui graduação em Sistemas e Mídias Digitais pela Universidade Federal do Ceará - UFC (2015), com graduação sanduíche no curso de Media na Soongsil University (Coréia do Sul) e graduação em Marketing pela Faculdade de Tecnologia Darcy Ribeiro - FTDR (2009). Possui Especialização em Tecnologias Digitais na Educação Básica (2019) pela Universidade Estadual do Ceará - UECE. Atualmente é professor e coordenador técnico do curso de Multimídia na EEEP Professora Alda Façanha. Atuou como designer e pesquisador de multimídia da Universidade Federal do Ceará. Tem experiência na área de Design Gráfico, Design de Jogos e llustração, atuando principalmente nos seguintes temas: design, tipografia, jogos de plataforma, gamificação e game design.

2 Doutor em Artes pela Escola de Belas Artes da Universidade Federal de Minas Gerais, Mestre em Informática Educativa pela Universidade Estadual do Ceará e Licenciado em Educação Artística (Lic.Plena) pela Universidade Federal do Rio Grande do Norte. Professor Titular do Programa de PósGraduação em Artes/Departamento de Artes/IFCE. Leciona no curso de Licenciatura em Artes Visuais, no Mestrado Profissional em Artes do IFCE e no Mestrado Profissional em Artes (PROFARTES) da Universidade Federal do Ceará. Membro da Associação Nacional de Pesquisadores em Artes Plásticas (ANPAP), do Comitê Educação em Artes Visuais, representante da Sessão Regional Ceará (2013-2020), $1^{\circ}$ secretário da ANPAP (biênio 2013-2014). Membro da Comissão Editorial da Revista ARJ (Art Research Journal) para o período 2020-2022, avaliador do Programa Nacional do Livro Didático (PNLD)/2015-ARTE, PNLD/2018 e Coordenador Pedagógico do PNLD/2019-ARTE. Realizou exposições individuais e coletivas em Fortaleza, Santa Maria -RS, Bulgária e New York; e lidera o Grupo de Pesquisa Arte UM/CNPQ-IFCE. Desenvolve pesquisas nos seguintes temas: Ensino de Arte e Gravura.
}

CARMO, Raphael de Alcântara do; LIMA, José Maximiano Arruda Ximenes de. As influências da arte abstrata nos jogos de tabuleiros modernos. Revista da FUNDARTE. Montenegro, p.01-26, ano 21, no 46, setembro de 2021.

Disponível em: http://seer.fundarte.rs.gov.br/index.php/RevistadaFundarte/issue/archive > 30 de setembro de 2021. 


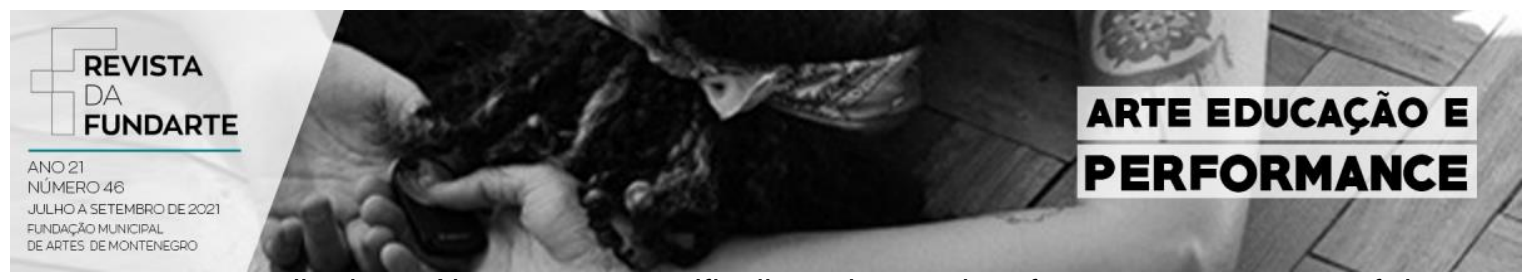

none proposes to talk about Abstract art specifically, using works of art as components of the game, but without delving into the theme.

Keywords: Abstract art; Board Games; Representation.

\section{INTRODUÇÃO}

Apesar da indústria de jogos digitais ser a principal e mais comum forma de jogar hoje em dia, os jogos analógicos, ou seja, aqueles não precisam de dispositivos digitais para ser jogados, ainda possuem uma grande fatia de mercado. De acordo com a Pesquisa Game Brasil (2019), 28\% dos brasileiros se divertem jogando jogos de tabuleiro, enquanto $34 \%$ preferem os jogos de cartas. O segmento representou $9,7 \%$ do faturamento do mercado de brinquedos e possui um crescimento de $7,5 \%$ ao ano. Atualmente, o boom desse tipo de jogos no Brasil é representado pelos chamados Jogos de Tabuleiro Modernos, ou Hobby Games. Esses jogos possuem mais foco em estratégia, duração mais curta e menos uso de sorte, sendo assim de mais fácil absorção por diversas faixas etárias (WOODS, 2012).

A Arte Abstrata, ou Abstracionismo, foi um período artístico iniciado no início do século XX. O principal objetivo dos abstracionistas era criar uma arte que se libertasse da representação da natureza. Importante afirmar que alguns autores preferem os termos "arte não figurativa" ou "arte não objetiva", visto que o seu objetivo não era representar as figuras na sua forma concreta. Além disso, os abstracionistas acreditavam que toda forma de arte já é uma abstração. Dito isso, então, o objetivo dos abstracionistas era criar uma abstração para as formas mais básicas da representação (GOMBRICH, 2010).

Jull (2007) estudou em seu trabalho os níveis de abstração que acontecem nos jogos quando eles adaptam outras situações para o contexto de jogabilidade. Para ele, a abstração nos jogos é importante para transferir aquela experiência que o jogo está simulando para uma situação que seja divertida e engajadora para o jogador. Rosa (2015) descreve em seu trabalho as relações que existem em alguns jogos digitais que utilizam gráficos abstratos com arte não figurativa. Ele analisa a

CARMO, Raphael de Alcântara do; LIMA, José Maximiano Arruda Ximenes de. As influências da arte abstrata nos jogos de tabuleiros modernos. Revista da FUNDARTE. Montenegro, p.01-26, ano 21, no 46, setembro de 2021.

Disponível em: http://seer.fundarte.rs.gov.br/index.php/RevistadaFundarte/issue/archive > 30 de setembro de 2021. 


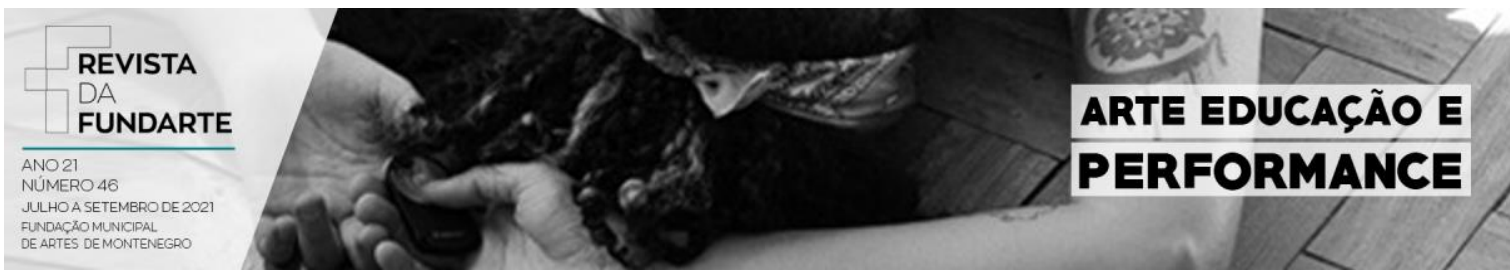

relação do jogador com esses mundos abstratos criados pelos jogos, fazendo um paralelo com as sensações que sentimos ao apreciar uma obra abstrata. Gomes (2019) produziu em seu trabalho um jogo de cartas adaptável para o ensino de artes visuais. O seu produto final consistia em um baralho de cartas que poderia ser adaptado para diferentes obras artísticas e usado como ferramenta de auxílio nas aulas de arte. Na literatura específica consultada, não foram encontrados trabalhos que falem sobre a arte abstrata nos jogos de tabuleiro ou mesmo analisando jogos que utilizem arte de forma geral como seu tema principal.

Percebendo a falta de estudos que abordem essa temática, este trabalho tem o objetivo de analisar o abstracionismo aplicado aos jogos de tabuleiro modernos, bem como analisar como os jogos que tratam sobre arte lidam com o assunto através das suas mecânicas de jogo e que tipo de abstrações esses jogos desenvolvem para adaptar o processo de pintura para suas regras.

\section{ARTE ABSTRATA}

Para entender os movimentos da Arte Abstrata, é preciso entender o contexto político que estava acontecendo na Europa no final do século XIX e início do século XX. A modernização e novas máquinas prometiam um mundo novo, ao mesmo tempo que apagavam o antigo. Existia um sentimento de renovação e inovação (GOMBRICH, 2010). Apesar desse aparente otimismo, a Europa, no início do século, passava por diversas disputas políticas e territoriais que culminaram na Primeira Guerra Mundial. Nesse contexto, também existia um sentimento de desespero e pessimismo crescentes. Essas mudanças de pensamento também influenciavam o dia a dia das pessoas. Na virada do século XIX para o XX, tivemos os primeiros trens elétricos, Einstein propôs a teoria da relatividade, as primeiras fotos em jornais puderam ser vistas pelo cidadão comum e o telefone passou a ser um item doméstico. Essas mudanças eram perceptíveis para as pessoas, e com os artistas não era diferente (LAMBERT, 1984). 


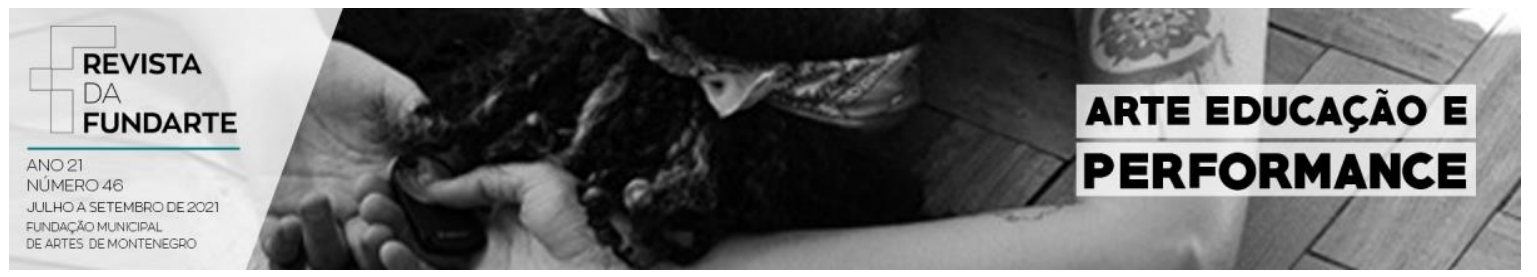

Esse rompimento com a tradição ocorreu desde a Revolução Francesa em 1789. Nos últimos séculos, os artistas eram pagos e contratados para pintar o que interessava aos poderosos e aos amantes das ditas belas artes. Dessa forma, os temas acabavam convergindo para religião, mitologia ou história, sendo, na maioria das vezes, com uma visão eurocêntrica do mundo. Durante o Renascimento, aquilo visto como Belo era uma representação da natureza através das artes (NUNES, 2005, p. 18): (Os apontamentos abaixo já estavam aqui)

\begin{abstract}
Foi no Renascimento que se deu a união de uma terceira ideia, a de Natureza, a qual nessa época adquiriu sentido preciso, ajudou a consumar. Conjunto de fenômeno sujeito a leis, contendo formas perfeitas, como pensava Leonardo da Vinci, a Natureza é a fonte do Belo que o artista revelará com suas próprias produções, às quais se concede uma consistência semelhante à do Universo material e sensível, agora valorizado. Falar-se-á, daí por diante, numa beleza natural, a que a arte tem que se sujeitar, e que, para ela transplantada, gera a beleza artística.
\end{abstract}

Os pintores da virada do século sentiram que esses temas não faziam parte das suas vidas e passaram a olhar para si mesmos, buscando expressar seus sentimentos mais íntimos nas suas obras, de forma menos representativa (LAMBERT, 1984).

Nesse contexto de apagamento do velho para criação de um novo, surge a Arte Moderna. Neste trabalho, vamos focar na Arte Abstrata, um dos movimentos que faz parte do modernismo. Os abstracionistas não procuravam mais representar a natureza da mesma forma como era representada no passado. Inspirados pelos impressionistas como Cézanne, Gauguin e Van Gogh, os abstracionistas entendiam que o próprio conceito de representação realista da natureza era algo contraditório. Para eles, toda arte já é uma abstração da realidade, pois o resultado final nunca será igual ao objeto real (GOMBRICH, 2010). Na Figura 1, podemos ver uma das primeiras obras de Kadinsky ainda seguindo as técnicas impressionistas.

CARMO, Raphael de Alcântara do; LIMA, José Maximiano Arruda Ximenes de. As influências da arte abstrata nos jogos de tabuleiros modernos. Revista da FUNDARTE. Montenegro, p.01-26, ano 21, no 46, setembro de 2021.

Disponível em: http://seer.fundarte.rs.gov.br/index.php/RevistadaFundarte/issue/archive > 30 de setembro de 2021. 

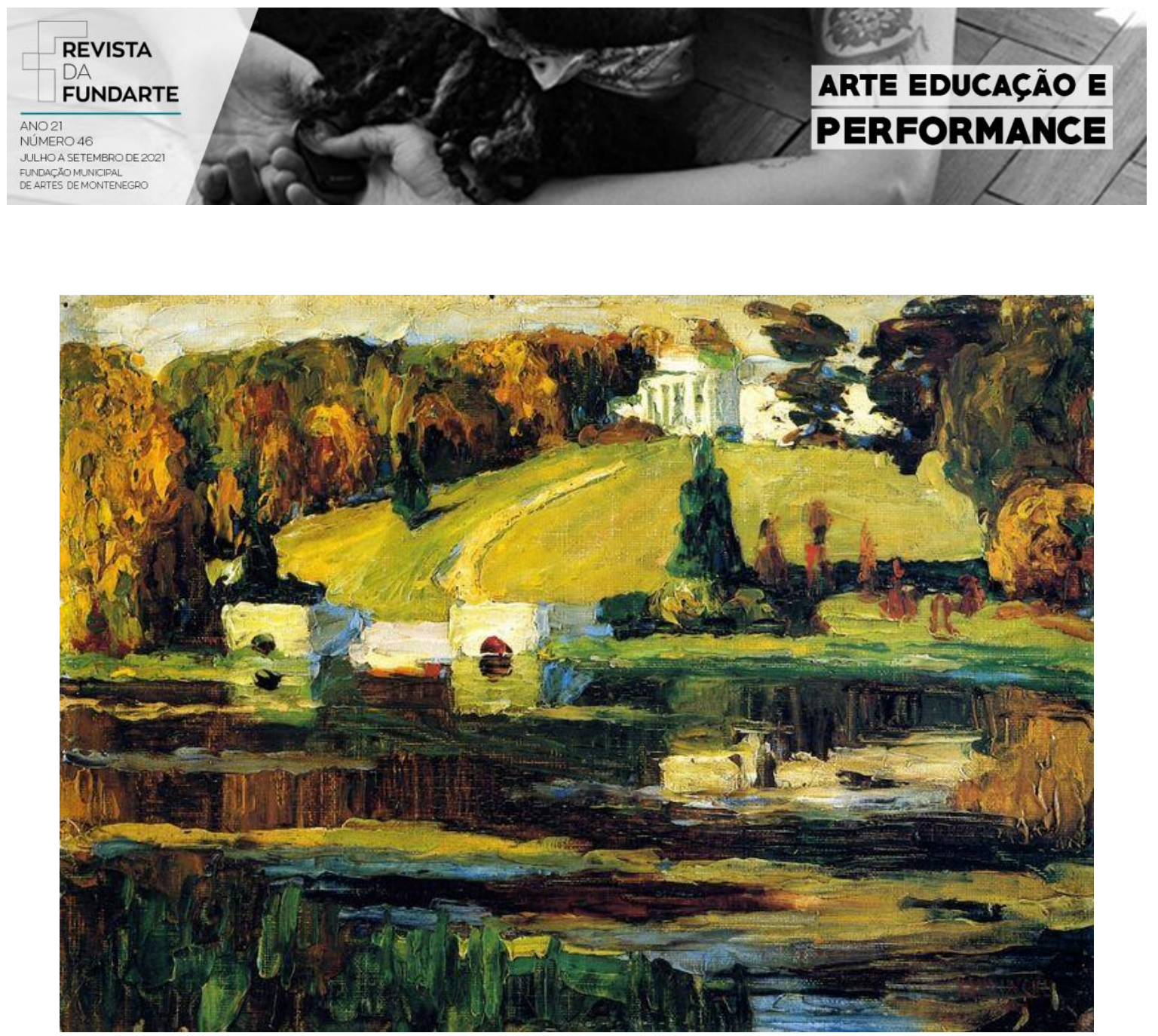

Figura 1: Akhtyrka - Outono (KANDINSKY, 1901). Fonte: WassilyKandinsky.net, 2020.

Além do Impressionismo, os abstracionistas buscaram também sua inspiração nas artes primitivas e na arte africana. Os artistas europeus desse período estavam buscando inspirações não só dentro do seu contexto e da sua sociedade, mas também procurando misturar conceitos e técnicas de fora. Tanto na arte africana como na arte primitiva, as representações de humanos ou outros seres eram de feitas de forma mais minimalista, nunca procurando representar o objeto em sua forma mais original, mas criando uma abstração que conseguia ser entendida pelo observador (PROENÇA, 2012).

De acordo com Gombrich (2010), Wassily Kandisnky foi o pintor responsável por iniciar o movimento abstracionista, pois foi um dos primeiros a expor uma pintura sem o objetivo de representar algum objeto encontrado na natureza. O pintor russo era uma pessoa de filosofia mística, que negava os valores e progresso da ciência. Ele acreditava na regeneração do mundo através de uma nova arte mais intimista.

CARMO, Raphael de Alcântara do; LIMA, José Maximiano Arruda Ximenes de. As influências da arte abstrata nos jogos de tabuleiros modernos. Revista da FUNDARTE. Montenegro, p.01-26, ano 21, no 46, setembro de 2021.

Disponível em: http://seer.fundarte.rs.gov.br/index.php/RevistadaFundarte/issue/archive $>30$ de setembro de 2021. 


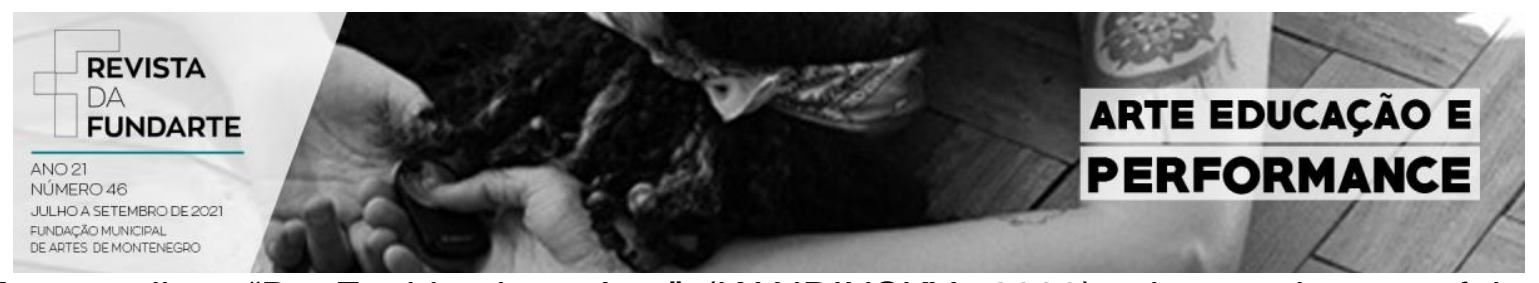

Em seu livro "Do Espiritual na Arte" (KANDINSKY, 2000), ele estudou os efeitos místicos e psicológicos das cores na mente das pessoas.

De acordo com Janson (1988), Kandinsky não queria simplificar as formas do mundo visível, mas criar algo totalmente novo sem relação com a natureza. Quaisquer semelhanças com o mundo real que pudéssemos ver em suas obras era não intencional, pois o pintor buscava representar as cores e formas eu seu estado puramente espiritual, eliminando sua semelhança com o mundo físico.

Dessa forma, podemos relacionar a arte de Kandinsky com as Belas Artes do Renascimento. Apesar de parecerem obras com objetivos diferentes, vemos aqui a mesma preocupação de representar o belo da natureza. A diferença é que no Abstracionismo existe uma preocupação em representar o belo em uma forma mais subjetiva, pura e espiritual.

Os quadros de Kandinsky buscavam fugir tanto da representação da natureza que suas obras remetem a títulos "musicais", usando a palavra "Composição" seguida de um número para diversos de seus quadros. As semelhanças e aproximações da pintura com os conceitos musicais salientam mais uma vez sua preocupação em tornar a arte visual algo mais intimista, sentimental e espiritual. Seus quadros, como composições musicais, despertam reações intuitivas na nossa mente (JANSON, 1988). Mesmo que não entendamos o que o pintor quis realmente passar com aquela obra, sentimos algo quando nos deparamos com ela, seja alguma reação química em nossa mente ou uma reação espiritual, como acreditava o pintor.

CARMO, Raphael de Alcântara do; LIMA, José Maximiano Arruda Ximenes de. As influências da arte abstrata nos jogos de tabuleiros modernos. Revista da FUNDARTE. Montenegro, p.01-26, ano 21, no 46, setembro de 2021.

Disponível em: http://seer.fundarte.rs.gov.br/index.php/RevistadaFundarte/issue/archive $>30$ de setembro de 2021. 

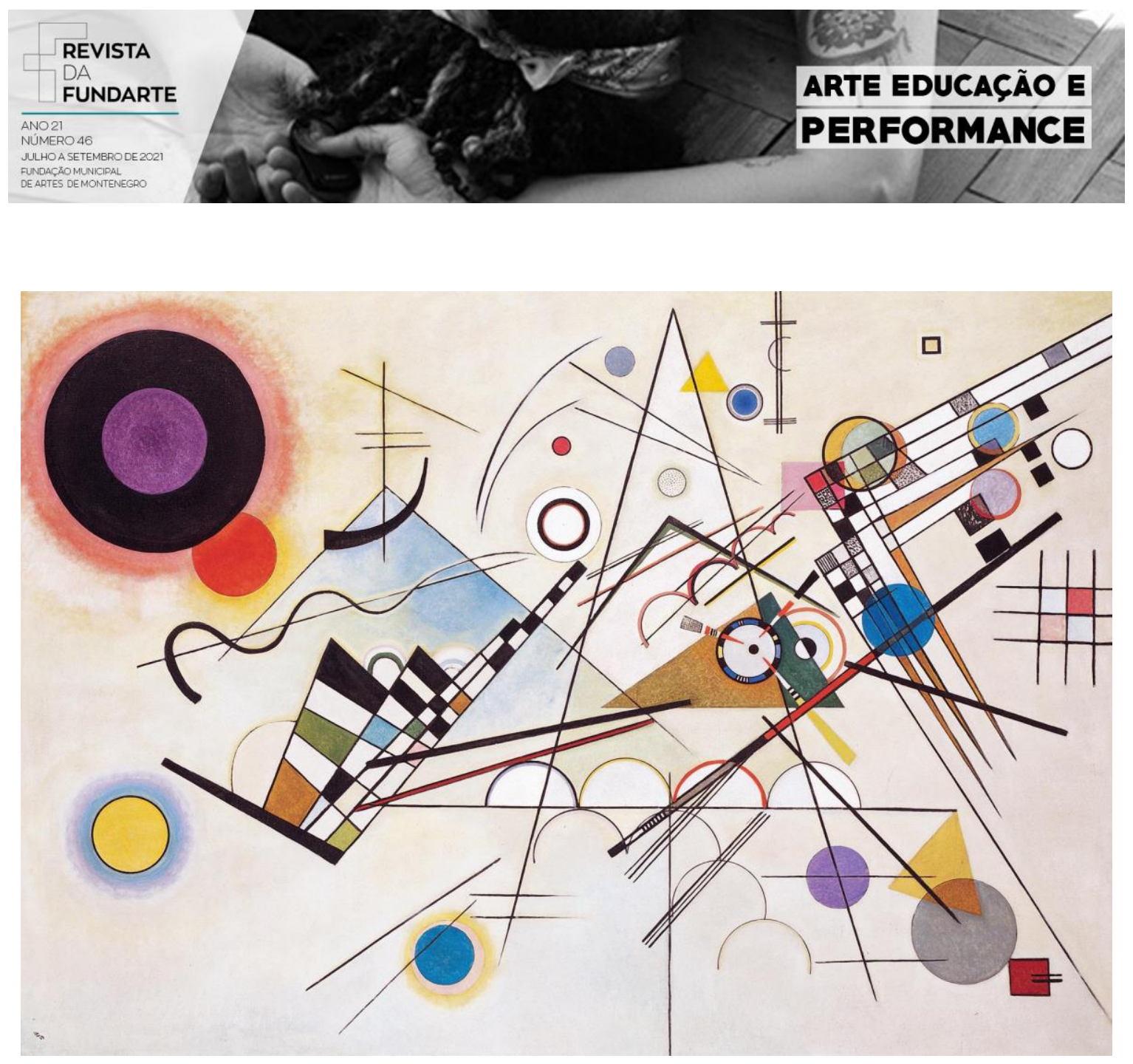

Figura 2: Composição VIII (KANDINSKY, 1923). Fonte: WassilyKandinsky.net, 2020.

Esse estudo dos efeitos da música nas pessoas não é algo novo. Platão já estudava os efeitos psicológicos e espirituais da música, conforme explicita Nunes (2005, p. 38):

Em relação a música, a doutrina mimética tem certas sutilezas. Assim, por exemplo, no terceiro livro de a república Platão relaciona a determinados modos harmônicos com determinados sentimentos e qualifica os ritmos pela escada moral das atitudes a ritmos que imitam abaixa e o desregramento existem harmonias patéticas, melancólicas e lânguidas como a entusiásticas, energéticas e marciais. É como se a música pudesse exteriorizar, no tempo, a qualidade afetiva dos sentimentos humanos. Ela imitaria, assim, um conteúdo psíquico ou moral dos pontos, a forma das combinações de sons corresponderia a forma característica do entusiasmo e da tristeza, da melancolia .

CARMO, Raphael de Alcântara do; LIMA, José Maximiano Arruda Ximenes de. As influências da arte abstrata nos jogos de tabuleiros modernos. Revista da FUNDARTE. Montenegro, p.01-26, ano 21, no 46, setembro de 2021.

Disponível em: http://seer.fundarte.rs.gov.br/index.php/RevistadaFundarte/issue/archive > 30 de setembro de 2021. 


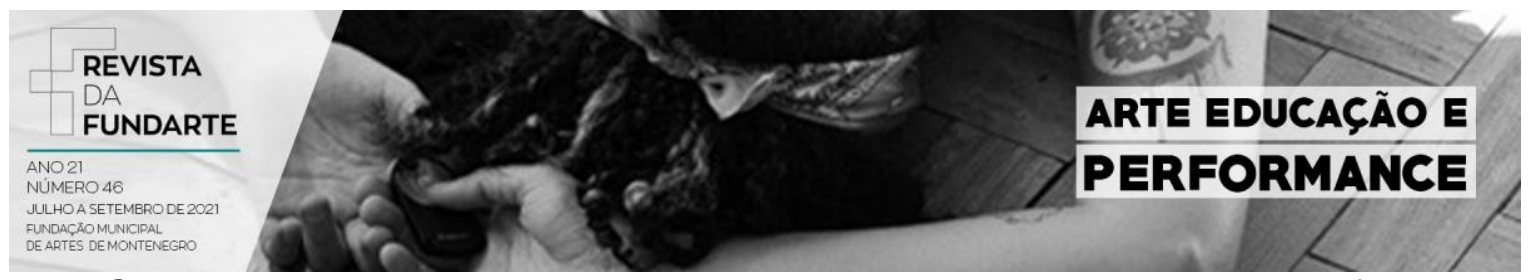

O objetivo de Kandinsky era justamente este. Produzir o mesmo efeito que a música traz ao expectador. Quando ouvimos um violino ou um trompete, aquilo não está representando nenhuma forma da natureza, mas de certa forma está nos trazendo imagens e cenas em nossa mente. $\mathrm{O}$ mesmo efeito acontece quando apreciamos uma obra do autor, as formas e cores representadas na tela não procuram representar a natureza de forma direta, mas subjetivamente nos trazem imagens, sentimentos e pensamentos diversos.

Para título de organização, alguns autores categorizam a Arte Abstrata em duas vertentes diferentes, sendo elas o Abstracionismo Informal e o Abstracionismo Geométrico. Por um lado, essa categorização facilita o entendimento e a separação entre pintores, mas por outro acaba por criar formas engessadas e limitadas de entender um movimento tão complexo.

Kandinsky fazia parte de uma das vertentes do Abstracionismo chamada por alguns autores de Abstracionismo Informal, também chamado de Abstracionismo Lírico ou Expressivo. Essa vertente tinha inspiração em movimentos como o Expressionismo e o Fauvismo e nele predominam formas e cores criadas livremente, usando de curvas e formas mais orgânicas. Por causa dessas formas mais naturais, muitas vezes podem acontecer associações com elementos da natureza, mesmo que isso não seja o objetivo do pintor (PROENÇA, 2012).

A outra vertente do Abstracionismo era chamada de Abstracionismo Geométrico. Nessa vertente, as cores e formas da composição devem ser organizadas de forma que a obra final seja uma concepção geométrica. O principal artista do Abstracionismo Geométrico foi o pintor holandês Piet Mondrian (PROENÇA, 2012). Nesse trabalho, focaremos no Abstracionismo Informal, mais precisamente na arte de Kandinsky.

CARMO, Raphael de Alcântara do; LIMA, José Maximiano Arruda Ximenes de. As influências da arte abstrata nos jogos de tabuleiros modernos. Revista da FUNDARTE. Montenegro, p.01-26, ano 21, no 46, setembro de 2021.

Disponível em: http://seer.fundarte.rs.gov.br/index.php/RevistadaFundarte/issue/archive $>30$ de setembro de 2021. 

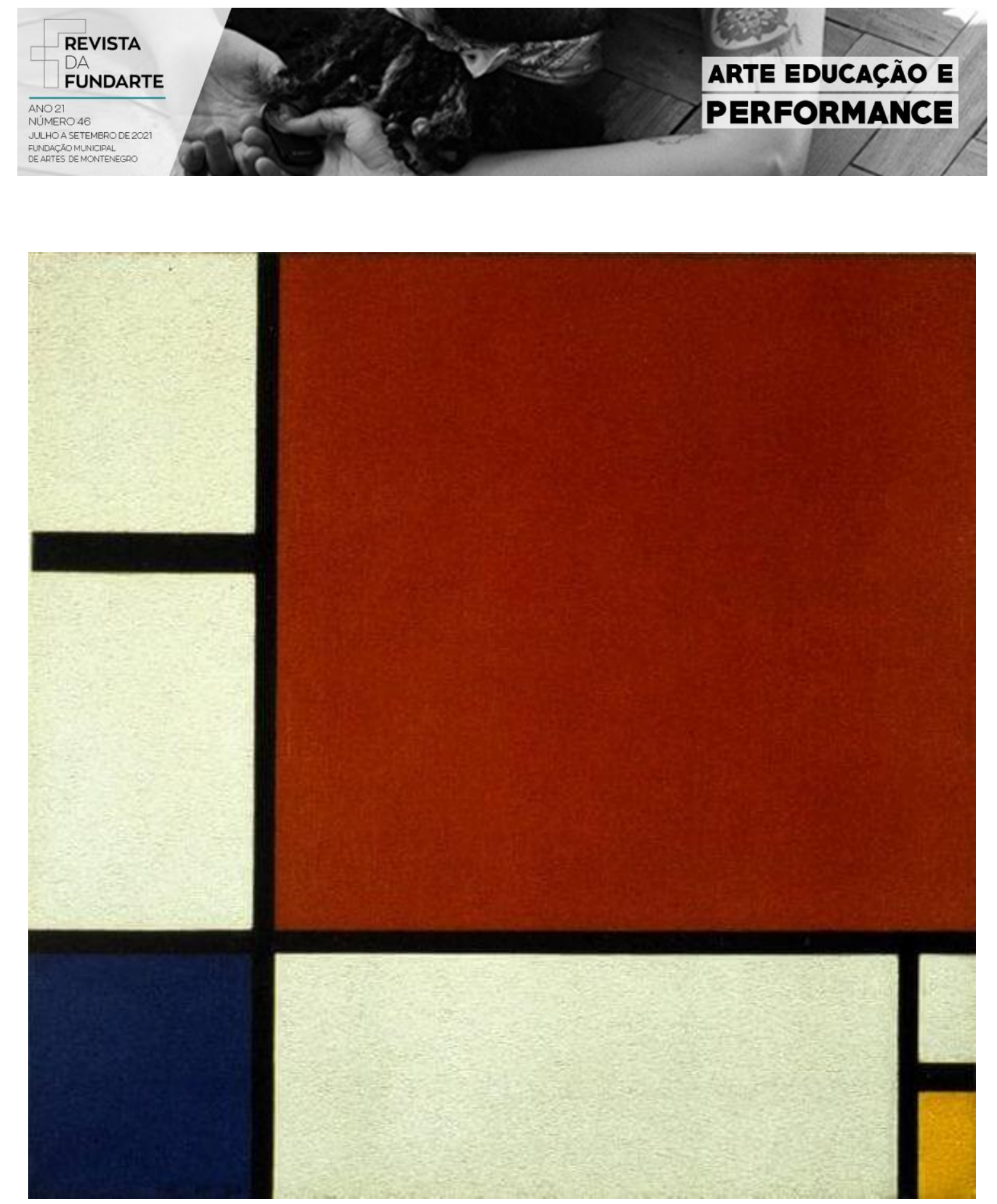

Figura 3: Composição II em vermelho, azul e amarelo (MONDRIAN, 1929). Fonte: Wikipedia, 2020.

Ao ler sobre Arte Abstrata, passamos a entender e respeitar mais esse movimento que foi perseguido e desacreditado pelos mais conservadores no início do século XX. De acordo com Gombrich (2010), é fácil entendermos a dificuldade de um artista ao tentar resolver o problema de relacionar formas e cores básicas em um quadro até que the pareçam corretos. Quando os artistas clássicos se deparavam com a situação de pintar uma pessoa ou um cenário, eles já tinham um objetivo em

CARMO, Raphael de Alcântara do; LIMA, José Maximiano Arruda Ximenes de. As influências da arte abstrata nos jogos de tabuleiros modernos. Revista da FUNDARTE. Montenegro, p.01-26, ano 21, no 46, setembro de 2021.

Disponível em: http://seer.fundarte.rs.gov.br/index.php/RevistadaFundarte/issue/archive $>30$ de setembro de 2021. 


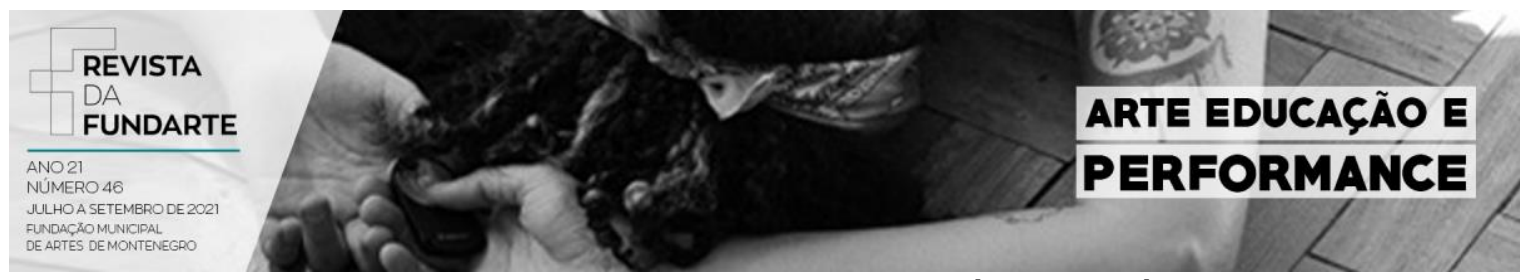

mente para ser alcançado e se apoiavam numa série de técnicas e estudos de outros profissionais que vieram antes deles. Os pintores abstratos estão em um terreno muito mais inóspito e sem um objetivo final, podendo passar muito mais tempo lutando contra uma obra sem saber nunca quando ela ficará pronta (GOMBRICH, 2010).

Para Worringer (1958, p. 26), o artista abstrato possui uma liberdade maior para produzir suas obras, pois ele não está preso à representação da natureza. Mas essa liberdade acaba afastando o artista de seu público.

Fica o questionamento, para quem produz esse artista? Não deve ser para o público comum, pois ainda presos nos hábitos da cultura renascentista, olha o quadro para ver algo representado. A pintura contemporânea exige do público uma educação artística, muito difícil de alcançar em uma época da cultura de massa. No final, os artistas estariam produzindo para outros artistas.

Através dessas análises, podemos perceber que a Arte Abstrata acaba sendo ainda mais elitista do que as consideradas Belas Artes do Renascimento. O público mais sensível pode apreciar esse tipo de arte, mas sem entender ao certo o porquê daquilo estar acontecendo. E o público não acostumado com esse estilo, pode vê-la como uma farsa ou como algo inferior, sem entender todo estudo que existe ali por trás.

\section{JOGOS DE TABULEIRO MODERNOS}

O termo "jogo de tabuleiro" se refere não somente a jogos que usam de fato um tabuleiro para se jogar. Muitos deles, por exemplo, utilizam somente cartas ou outros componentes. Por questão de simplificação, o termo "jogo de tabuleiro" é mais comumente usado (WOODS, 2012).

Atualmente, os jogos de tabuleiro podem ser divididos em 3 categorias, segundo Woods (2012):

CARMO, Raphael de Alcântara do; LIMA, José Maximiano Arruda Ximenes de. As influências da arte abstrata nos jogos de tabuleiros modernos. Revista da FUNDARTE. Montenegro, p.01-26, ano 21, no 46, setembro de 2021.

Disponível em: http://seer.fundarte.rs.gov.br/index.php/RevistadaFundarte/issue/archive > 30 de setembro de 2021 . 


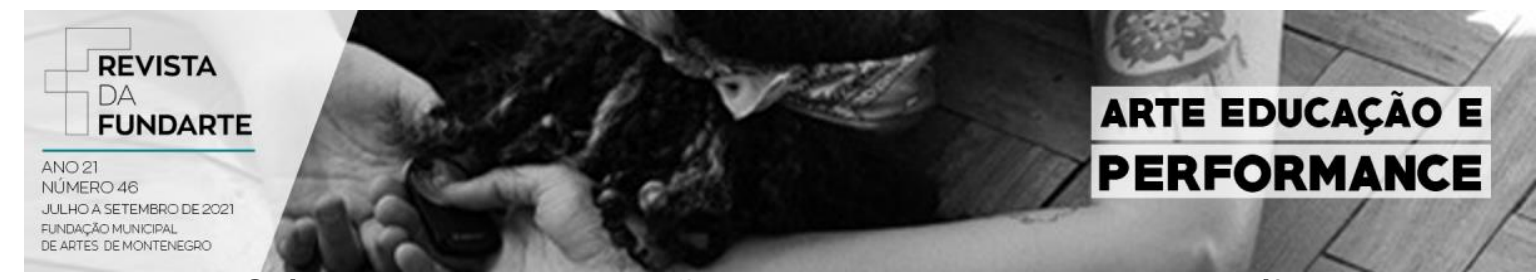

- Jogos Clássicos: Jogos que não possuem uma autoria específica e que estão em domínio público, ou seja, nenhuma empresa detém os seus direitos e podem ser distribuídos por qualquer editora ou companhia. Geralmente esses jogos não possuem uma temática específica, sendo na sua maioria com temas abstratos. Exemplos comuns desses jogos são Xadrez ou Damas.

- Jogos de Mercado de Massa: Jogos comerciais que são vendidos em larga escala em lojas de departamento ou lojas de brinquedo, cujos direitos autorais são possuídos por alguma empresa. Esses jogos constituem a percepção comum sobre jogos de tabuleiro e muitas vezes utilizam temáticas de marcas famosas de TV ou cinema para atingir um mercado maior. Alguns exemplos são Banco Imobiliário (GROW, 1935) e War (GROW, 1975).

- Hobby Games: Jogos que não focam no mercado geral, mas sim em um grupo mais específico. Jogos de RPG de papel como Dungeons \& Dragons (Wizards of The Coast, 1974), jogos de cartas colecionáveis como Magic: The Gathering (Wizards of The Coast, 1993) e os jogos de tabuleiro modernos entram nessa categoria.

Dentre esses, os Hobby Games são os menos conhecidos. Parlett (1999, p. 6) traz uma definição para esses jogos, também chamados por ele de "jogos especializados":

Esses podem ser categorizados como jogos de habilidade e estratégia com apelo para jogadores descritos como adultos, sérios, educados e inteligentes. Muitos desses compartilham as características dos jogos clássicos, a categoria que eles somente diferem por ter um apelo a uma sessão mais especialista do mercado.

Parlett se refere mais especificamente a jogos que surgiram na metade do século XX que não se encaixavam nas categorias de clássicos ou de mercado de massa. Esse tipo de jogo é comumente chamado de hobby game. Dentro dos Hobby 


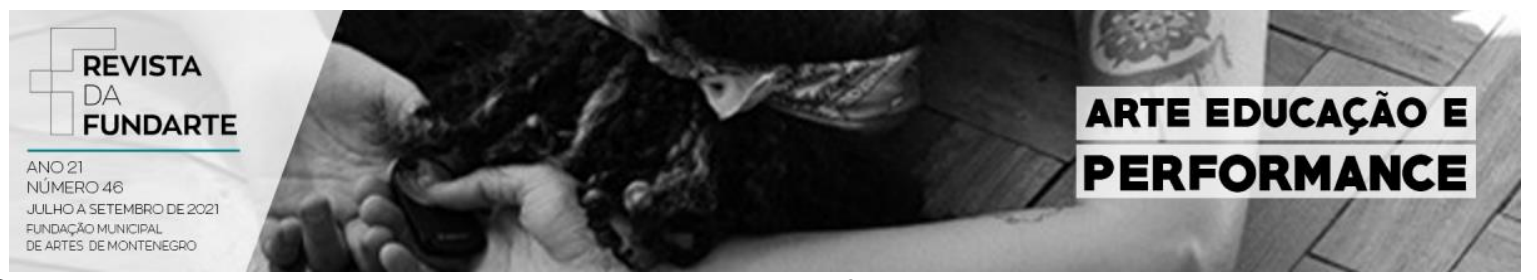

Games temos mais quatro subcategorias definidas por Aleknevicus apud Woods (2012). São elas:

RPG:

Sigla em inglês para Role Playing Games (Jogo de Interpretação de Papéis). Jogos em que os jogadores interpretam personagens utilizando geralmente papéis, lápis e dados.

Jogos de

cartas colecionáveis: Nesses jogos os jogadores compram pacotes de cartas para montar baralhos e enfrentar outros jogadores.

Wargam

es: Jogos que geralmente procuram simular combates militares. São jogos de longa duração, com bastante uso de sorte e temática forte para engajar o jogador.

Eurogam

es: Jogos mais acessíveis que privilegiam a estratégia em detrimento da sorte, possuem duração mais curta e não possuem muito foco na temática.

Os Eurogames são os mais atuais dessa lista. Eles se popularizaram com a fama do jogo Catan, de Klaus Teuber (KOSMOS, 1995), um designer alemão. Eles são jogos mais acessíveis que privilegiam as mecânicas, regras e estratégias no lugar do tema na sua jogabilidade. Eles geralmente priorizam conflito indireto no lugar de conflito direto, evitam o fator sorte, oferecem uma duração de partidas previsíveis e geralmente possuem componentes com um alto nível de qualidade e apresentação (WOODS, 2012).

Os antigos e famosos wargames dos anos 1970 que faziam sucesso nos Estados Unidos tentavam representar batalhas da forma mais realista possível com diversas tabelas, regras complexas e uma forte temática. Mesmo depois de anos, os chamados Amerigames, ou Ameritrashs atualmente ainda dependem de temática forte que converse com as mecânicas do jogo, sendo muito difícil separar esses dois abstrata nos jogos de tabuleiros modernos. Revista da FUNDARTE. Montenegro, p.01-26, ano 21, nํㅜ 46, setembro de 2021. 


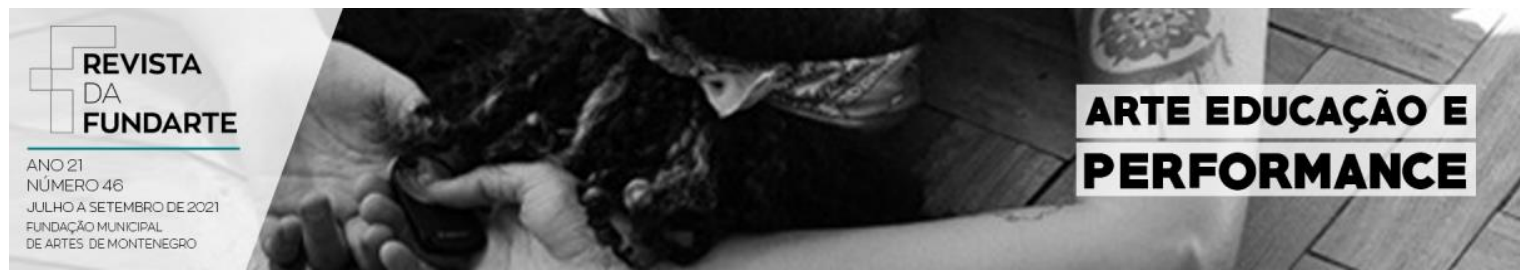

elementos. Esses jogos geralmente vêm acompanhados de miniaturas de plástico e artes representativas mais realistas para reforçar a história que estão contando e criar um sentimento de imersão (WOODS, 2012).

$\mathrm{Na}$ Figura 4, vemos o exemplo do jogo Twilight Imperium: Fourth Edition (Fantasy Flight Games, 2017), um jogo sobre conquista e batalhas espaciais. Dessa forma, podemos entender esse tipo de jogo como uma forma de representar a realidade de forma mais fiel. A quantidade exagerada de regras e o uso de componentes e ilustrações bem detalhadas servem para imergir o jogador nessa experiência.

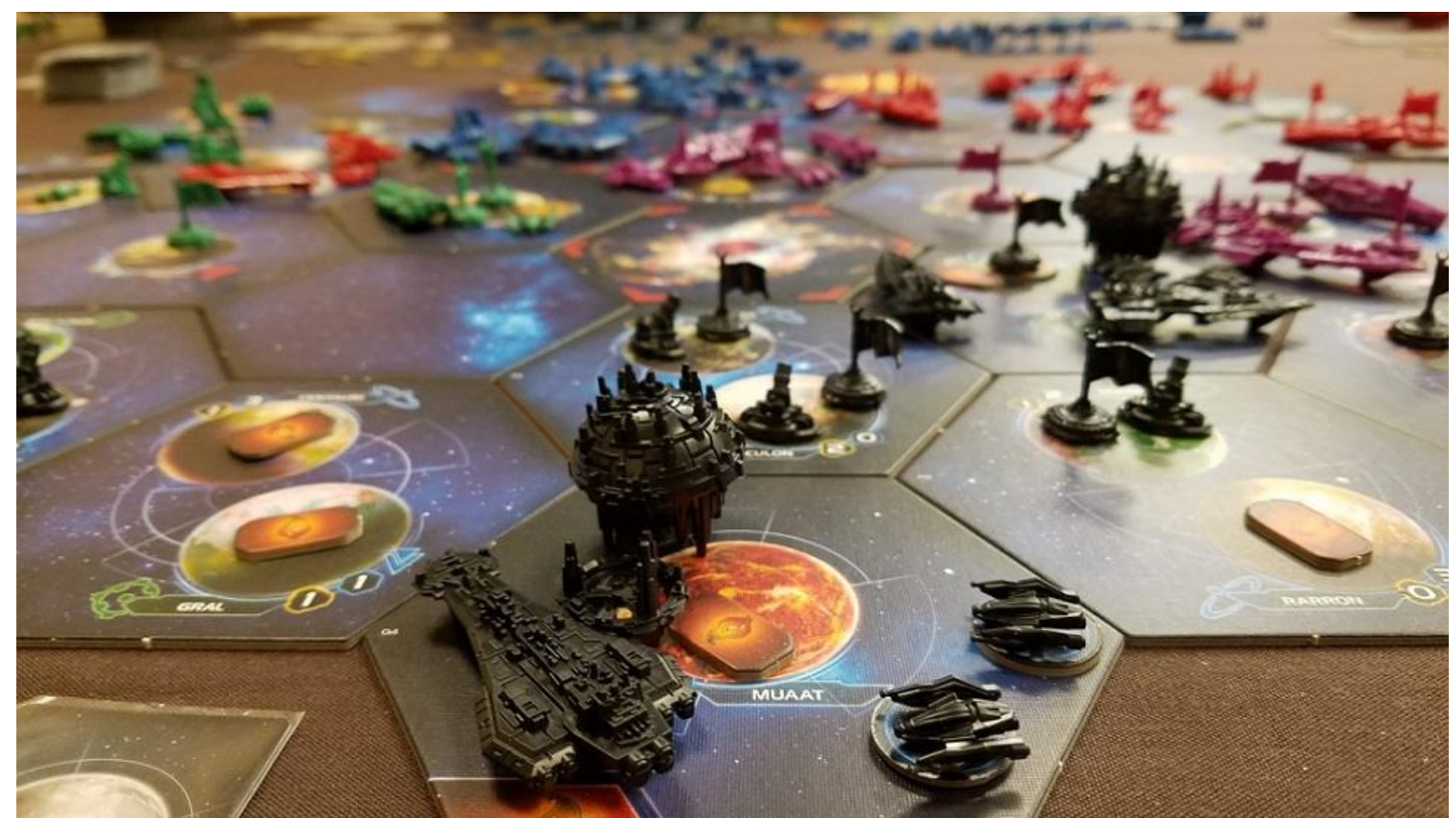

Figura 4: Twilight Imperium: Fourth Edition (Fantasy Flight Games, 2017). Fonte: BoardGameGeek, 2020.

Já os Eurogames construíram sua fama nos anos 90 e geralmente colocam a temática em segundo plano. Esses jogos possuem um nível maior de abstração, pois muitas vezes representam recursos ou elementos com componentes simples como cubos de madeira. Apesar de possuírem também artes de tabuleiro ou de cartas que buscam representar o mundo real, eles utilizam componentes e regras mais minimalistas, não tentando representar a realidade em sua totalidade, mas

CARMO, Raphael de Alcântara do; LIMA, José Maximiano Arruda Ximenes de. As influências da arte abstrata nos jogos de tabuleiros modernos. Revista da FUNDARTE. Montenegro, p.01-26, ano 21, no 46, setembro de 2021.

Disponível em: http://seer.fundarte.rs.gov.br/index.php/RevistadaFundarte/issue/archive > 30 de setembro de 2021. 


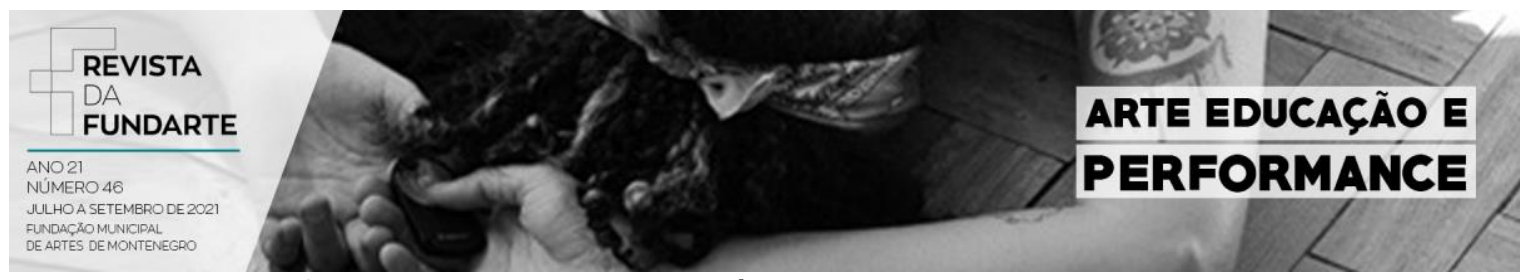

fazendo concessões pelo bem da experiência de um jogo menos complexo, ou seja, com regras reduzidas e mais fáceis de explicar para novos jogadores. Muitas vezes, a concepção do jogo vem inicialmente de uma mecânica ou regra interessante criada pelo designer, e a temática, mundo ou narrativa em que o jogo se passa vai ser adicionado somente no final do processo (WOODS, 2012).

Utilizando essa abstração na arte e nos componentes em diferentes contextos, podemos ter o mesmo componente significando coisas diferentes em jogos distintos. Com por exemplo, no jogo Lords of Waterdeep (Wizards of the Coast, 2012), os jogadores controlam lordes de uma cidade de fantasia medieval que devem contratar heróis de diferentes profissões para completar missões. Nesse jogo, cubos vermelhos representam guerreiros, cubos pretos são ladrões e cubos roxos são feiticeiros. Esses cubos são usados como recursos pelos jogadores para comprar cartas de objetivo e ganhar pontos para vencer o jogo. Já no jogo Pandemic (Z-Man Games, 2008), cubos de diferentes cores representam tipos de doença diferentes que precisam ser curadas. Esses cubos são espalhados por um mapa mundial e os jogadores precisam realizar ações para retirar esses cubos do tabuleiro e finalmente erradicar as doenças. Esses são dois exemplos de como o mesmo componente pode ser utilizado tanto tematicamente como mecanicamente em jogos distintos. Utilizando de uma temática envolvida nas mecânicas do jogo, o jogador abstrai esses componentes como elementos que encaixam naquela narrativa específica.

CARMO, Raphael de Alcântara do; LIMA, José Maximiano Arruda Ximenes de. As influências da arte abstrata nos jogos de tabuleiros modernos. Revista da FUNDARTE. Montenegro, p.01-26, ano 21, no 46, setembro de 2021.

Disponível em: http://seer.fundarte.rs.gov.br/index.php/RevistadaFundarte/issue/archive > 30 de setembro de 2021. 

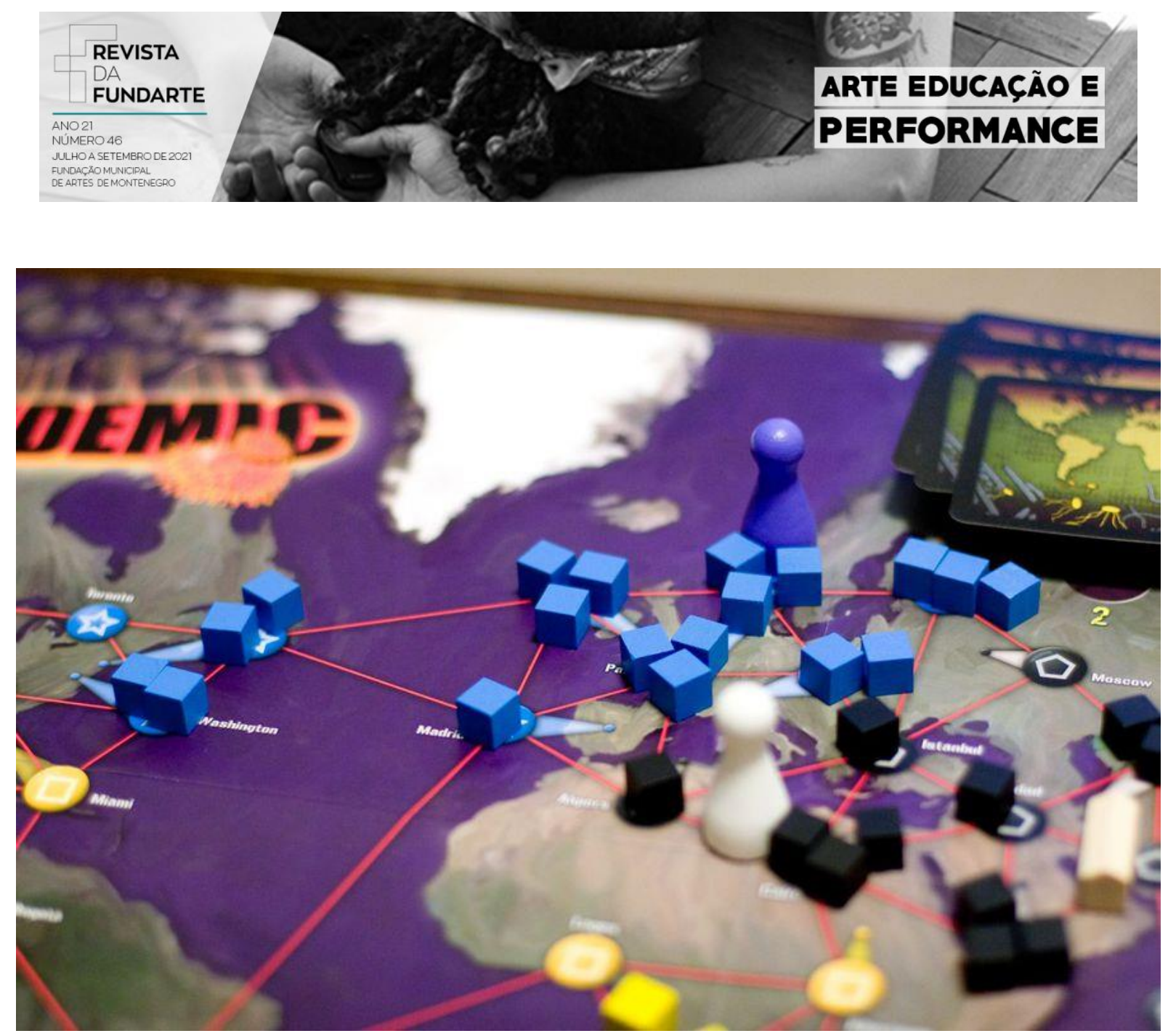

Figura 5: Pandemic (Z-Man Games, 2008). Fonte: BoardGameGeek, 2020

Outra abstração comum em jogos de tabuleiro como Pandemic é a adaptação de um mapa real em uma interface que favoreça a diversão e as mecânicas do jogo. $O$ tabuleiro de jogos como Pandemic ou War (Grow, 1975) é uma representação não real do mapa do mundo com cidades e países em localidades diferentes do que são normalmente. $O$ jogo busca ser uma simulação de uma situação real, mas de uma forma que consiga manter o jogador engajado e motivado. Colocar todos os países do mundo no mesmo tabuleiro deixaria a experiência complexa e poluída demais.

CARMO, Raphael de Alcântara do; LIMA, José Maximiano Arruda Ximenes de. As influências da arte abstrata nos jogos de tabuleiros modernos. Revista da FUNDARTE. Montenegro, p.01-26, ano 21, no 46, setembro de 2021.

Disponível em: http://seer.fundarte.rs.gov.br/index.php/RevistadaFundarte/issue/archive > 30 de setembro de 2021. 


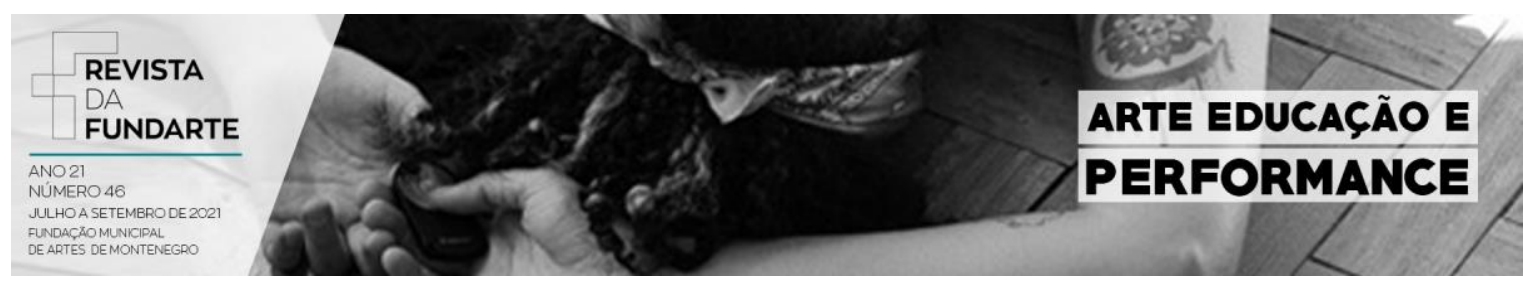

ABSTRACIONISMO E JOGOS DE TABULEIRO

Nesse tópico é discutido como acontece a abstração em jogos de tabuleiro e como a arte abstrata é representada e utilizada em alguns desses jogos.

Como toda forma de arte é uma abstração, todo jogo também se configura como uma abstração de uma situação real. De acordo com Jull (2007), todos os jogos que representam alguma situação possuem um nível de abstração. O jogador vai interagir com o mundo dentro das regras e limitações por ele estabelecidas. Para Jull, os jogos possuem elementos como regras e fiç̧ão (a temática ou história do jogo). O nível de abstração do jogador é definido por esse limite entre o que é totalmente ficcional e aquilo que interage com as regras do jogo. Por exemplo, em um jogo de cozinha, o jogador poderá cortar e cozinhar ingredientes, mas não existe um jogo que vai representar toda a experiência de uma cozinha na sua totalidade.

Para falar sobre abstração em jogos, é importante descrever as interações que existem entre mecânica e temática. Para Forbeck (2011), "As mecânicas são o modo abstrato de como o jogo funciona. A metáfora é a linda mentira contada pelo jogo, a ficção que dá ao jogo contexto e um significado amplo" (p. 32). A metáfora descrita por Forbeck (2011) é a temática do jogo, ou seja, a ambientação ficcional onde o jogo se passa. As mecânicas são definidas como as regras conversam entre si para formar o sistema onde esse jogo vai ser jogado. Um conjunto de regras vai limitar o jogador a atingir os objetivos do jogo, cabendo ao jogador se utilizar de habilidade ou estratégia para completar os objetivos do jogo dentro da abstração criada pelas regras.

Para Daviauํㄹ (2011), um jogo analógico deve ter dicas visuais para ajudar o jogador em seus componentes. Se cartas ou locais no tabuleiro possuem cores diferentes, eles devem servir para coisas diferentes ou devem ser separados.

Se usarmos o jogo previamente citado como exemplo, Lords of Waterdeep (Wizards of the Coast, 2012), percebemos que ele usa cores diferentes nos cubos de madeira para representar tipos diferentes de personagens. $O$ cubo branco representa 0 clérigo, o cubo laranja é o guerreiro, o preto é o ladino e, por fim, o roxo representa o

CARMO, Raphael de Alcântara do; LIMA, José Maximiano Arruda Ximenes de. As influências da arte abstrata nos jogos de tabuleiros modernos. Revista da FUNDARTE. Montenegro, p.01-26, ano 21, no 46, setembro de 2021.

Disponível em: http://seer.fundarte.rs.gov.br/index.php/RevistadaFundarte/issue/archive $>30$ de setembro de 2021. 


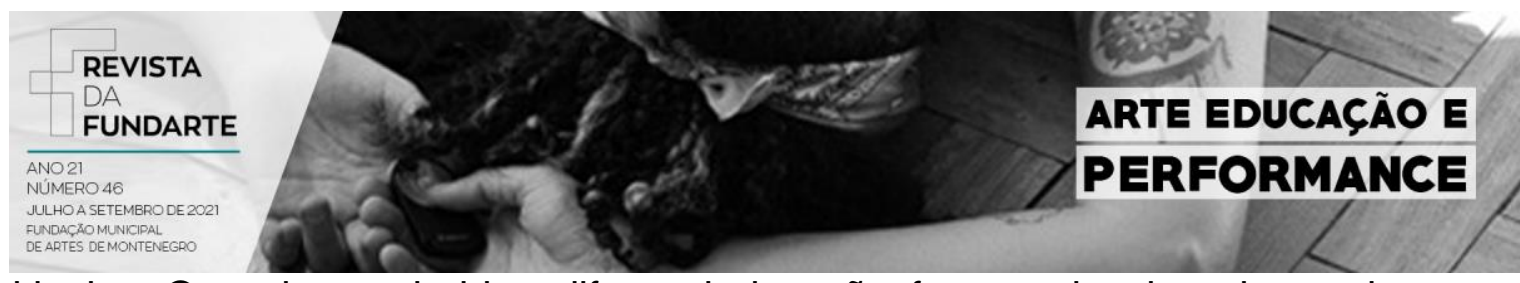

feiticeiro. Os cubos coloridos diferenciados são formas de abstrair as classes de personagens comuns nos jogos de RPG de mesa.

O branco, descrito por Kandinsky (1912), é uma mistura de todas as cores como um silêncio cheio de possibilidades que se alastra de forma infinita. Dessa forma, podemos perceber que essa ressonância quase que celestial do branco se conecta com o clérigo, representado nos jogos de RPG como alguém que tira seu poder dos deuses. O laranja, usado para representar o guerreiro, é uma mistura do vermelho e do amarelo que transborda energia. Nas palavras de Kandinsky (1912) sobre a cor laranja: "É como um homem seguro de sua força e que dá a impressão de saúde" (p. 43). Essa descrição faz todo sentido com o papel do guerreiro, que geralmente representa alguém que utiliza a força física para resolver os problemas. O cubo preto representa o ladino (também chamado de ladrão), uma profissional atribuída a personagens que trabalham nas sombras de forma furtiva. O preto, para Kandinsky, representa o silêncio da morte, a noite, o fim da luz do sol. Por fim, o roxo, utilizado para representar o feiticeiro, é descrito pelo pintor como uma cor que se distancia do homem, por ser uma cor que mistura o calor do vermelho com o frio do azul, torna-se algo que foge do natural, quase que mágico.

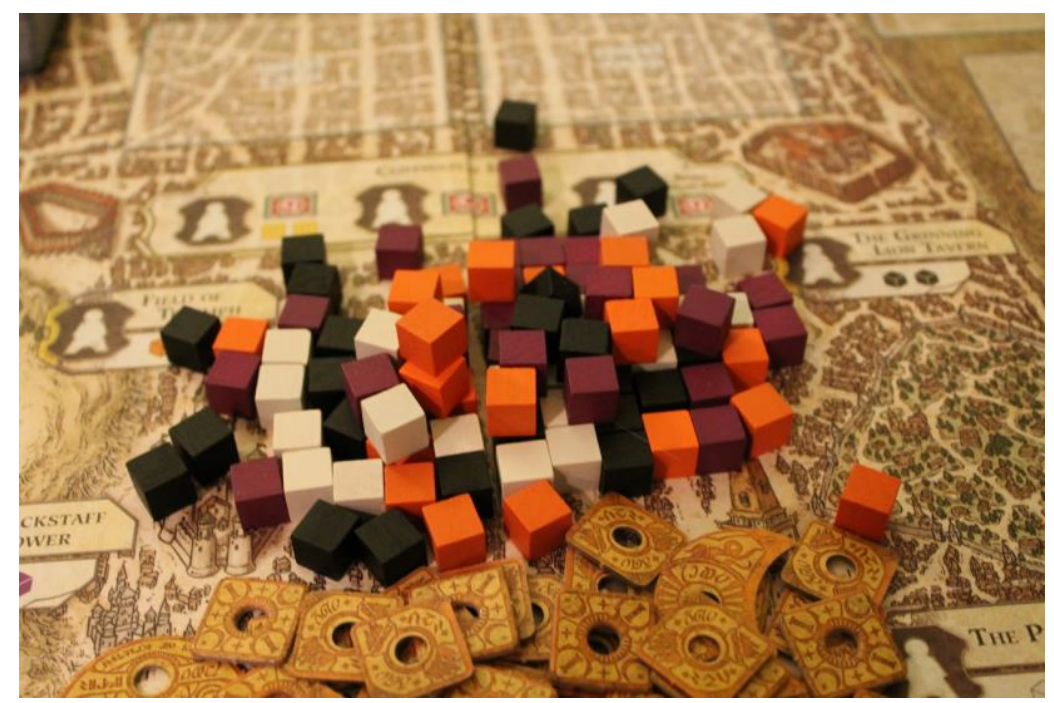

Figura 6: Lords of Waterdeep (Wizards of the Coast, 2012). Fonte: BoardgameGeek, 2020.

CARMO, Raphael de Alcântara do; LIMA, José Maximiano Arruda Ximenes de. As influências da arte abstrata nos jogos de tabuleiros modernos. Revista da FUNDARTE. Montenegro, p.01-26, ano 21, no 46, setembro de 2021.

Disponível em: http://seer.fundarte.rs.gov.br/index.php/RevistadaFundarte/issue/archive $>30$ de setembro de 2021. 


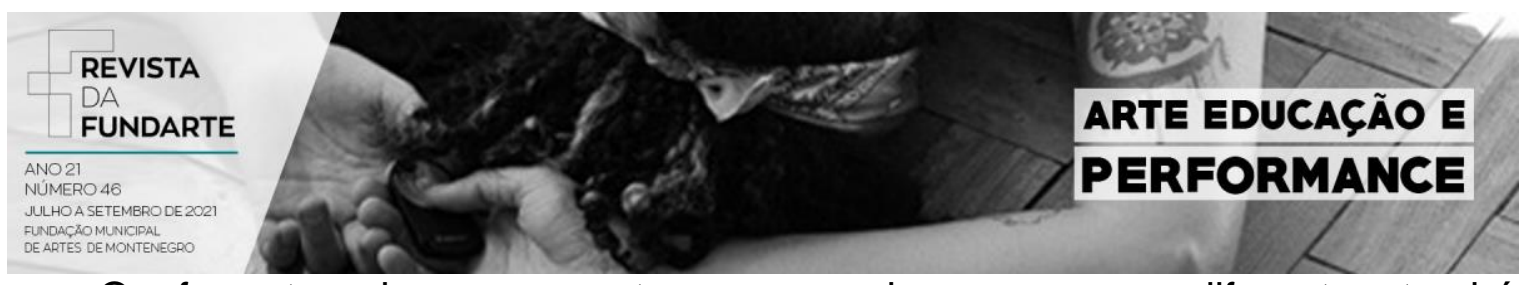

Os formatos de componentes como cubos ou peças diferentes também devem passar rapidamente ao jogador informações sobre como usá-los e como eles funcionam em seu jogo. $\mathrm{O}$ abstracionismo ou minimalismo pode servir para passar esses pedaços de informação de forma rápida e simples para os jogadores. Os quadrados ou cubos representam formas mais sérias, fixas, sem muito movimento. Os círculos são as formas com menos tensão, pois são formados de ângulos abertos que não possuem início nem fim. Os triângulos possuem uma tensão criada pelos ângulos fechados e apontam para alguma direção, indicando movimento. De toda forma, como informa Kandinsky (1926), as cores aplicadas a essas formas também fazem-nas se diferenciarem, isto é, um triângulo amarelo é diferente de um triângulo verde, e, por isso, cada um tem uma função distinta. Cada cor vai adicionar uma ressonância diferente, modificando o modo como vemos aquela forma.

Se levarmos em consideração a filosofia do abstracionismo como uma falta de representação da natureza, os tipos de jogos que mais buscam o abstracionismo são os Jogos de Estratégia Abstrata. Esses jogos geralmente não possuem um tema ou história, sendo majoritariamente mecânicos e com o mínimo de sorte envolvida (WOODS, 2012). Alguns exemplos de jogos abstratos são Xadrez, Damas ou Go. Esses jogos possuem peças com formas e cores simples que não necessariamente representam situações ou formas do mundo real. Mesmo que alguns jogos, como o Xadrez, ainda possuam certa conexão com o sistema feudal europeu, por exemplo, a mecânica do jogo possui um nível de abstração muito grande, desconectando-se quase totalmente da temática inserida. Jogadores de xadrez não precisam entender a situação que está sendo representada no tabuleiro para vencer. De acordo com Jull (2007), a abstração em jogos acontece muitas vezes quando o jogador ignora tudo aquilo que não é importante para que ele adquira a vitória, como uma forma de maximizar suas chances de vencer.

Curiosamente, ao se deparar com um tabuleiro de um jogo abstrato no meio de uma partida, é difícil não fazer uma clara conexão com um quadro de Arte Abstrata. Observamos as linhas, as formas e tensões criadas através de um processo caótico entre jogadores competindo entre si e colocando componentes no abstrata nos jogos de tabuleiros modernos. Revista da FUNDARTE. Montenegro, p.01-26, ano 21, no 46, setembro de 2021.

Disponível em: http://seer.fundarte.rs.gov.br/index.php/RevistadaFundarte/issue/archive $>30$ de setembro de 2021. 


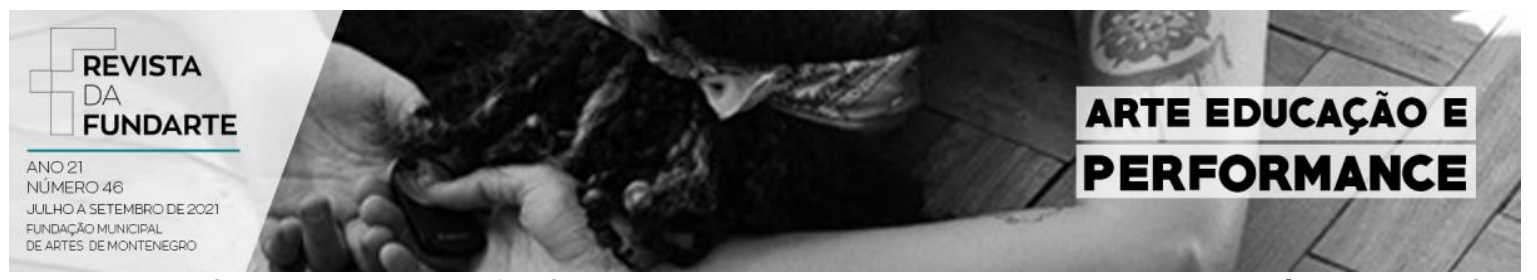

tabuleiro. A forma criada não foi pensada para ser assim desde o início, mas foi o resultado de um processo, como em uma pintura de Pollock.

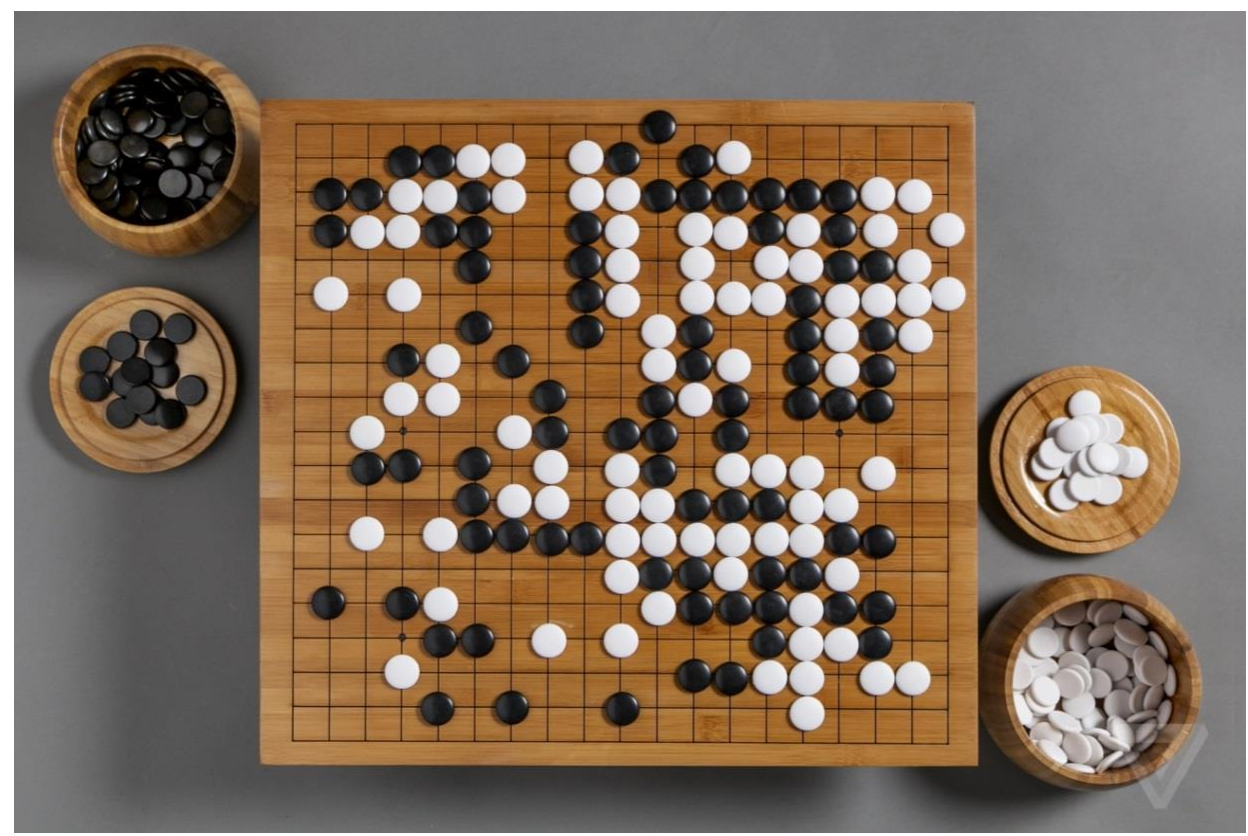

Figura 7: Tabuleiro de Go. Fonte: Canaltech, 2020.

Os diversos tipos de arte ou, mais especificamente, a Arte Abstrata, podem também ser usados como inspiração para temáticas de jogos de tabuleiro. $\mathrm{O}$ site Board Game Geek, o maior portal online sobre jogos de tabuleiro, com mais de 100 mil jogos listados (WOODS, 2012), enumera 167 jogos que possuem a temática de artes ou referenciam artes em suas regras. Alguns jogos colocam o jogador como uma pessoa que compra e vende obras de artes em leilões e outros em que o jogador é o próprio artista em busca de produzir os melhores quadros. Dos jogos analisados, poucos possuem alguma representação ou temática focada especificamente em Arte Abstrata. A seguir são detalhados alguns exemplos de jogos mais famosos com temática artística, de acordo com o portal Board Game Geek.

Em The Gallerist (Eagle-Gryphon Games, 2015), um dos mais famosos e bem avaliados jogos que utilizam arte como tema, o jogador fica encarregado de gerenciar um museu. No jogo, pode-se vender e comprar obras de arte, gerenciar

CARMO, Raphael de Alcântara do; LIMA, José Maximiano Arruda Ximenes de. As influências da arte abstrata nos jogos de tabuleiros modernos. Revista da FUNDARTE. Montenegro, p.01-26, ano 21, no 46, setembro de 2021.

Disponível em: http://seer.fundarte.rs.gov.br/index.php/RevistadaFundarte/issue/archive $>30$ de setembro de 2021. 


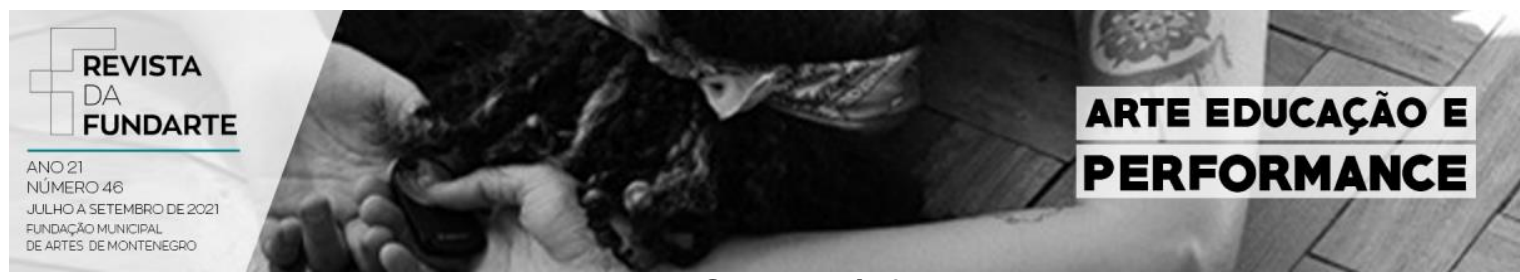

artistas e organizar galerias de arte. $\mathrm{O}$ jogo é focado muito mais no mercado de artes do que no processo artístico em si, tal como Modern Art (Hans im Glück, 1992), outro jogo que é focado somente nos leilões de compra e venda de obras de arte. Em ambos, o vencedor é o jogador que adquirir mais dinheiro ao final da partida. Em Cubist (Bright World Games, 2014), a temática também é sobre construir um museu de Arte Moderna, mas possui uma mudança criativa: os jogadores usam dados coloridos como materiais para a construção de galerias desses museus. $O$ jogo também possui algumas cartas com pinturas cubistas famosas que servem como habilidades especiais para o jogador.

Existem também jogos de tabuleiros em que o jogador imerge no papel do artista e precisa gerenciar seus recursos para realizar pinturas. Em Colors of Paris (Super Meeple, 2019), os jogadores são artistas em uma competição amigável na oficina de Montmartre, em Paris. O principal recurso do jogo para conseguir a vitória são cubos coloridos que representam tubos de tinta. No jogo, os jogadores precisam coletar, misturar e gerenciar tubos de cor para completar obras de arte que exigem essas cores específicas. Caso o jogador consiga as cores exigidas pelas cartas, ele ganha pontos de vitória. Nesse jogo, o processo da pintura é mais detalhado, pois o jogador precisa misturar cores para conseguir outras. Por exemplo, usar um cubo azul e outro vermelho para adquirir um cubo roxo, representando os cubos de cor como o dinheiro do jogo. Outro jogo que também usa essa mesma mecânica de coletar cubos coloridos para completar pinturas é Starving Artists (Deep Water Games, 2017). Nesse jogo, os jogadores precisam completar pinturas para vendêlas e comprar comida. Dessa forma ele faz uma discussão bem humorada e uma crítica sobre as dificuldades de viver de arte. Além disso, o jogo também possui pinturas famosas com o nome do artista e data, dando informações ao jogador sobre aquelas obras. abstrata nos jogos de tabuleiros modernos. Revista da FUNDARTE. Montenegro, p.01-26, ano 21, no 46 , setembro de 2021. 

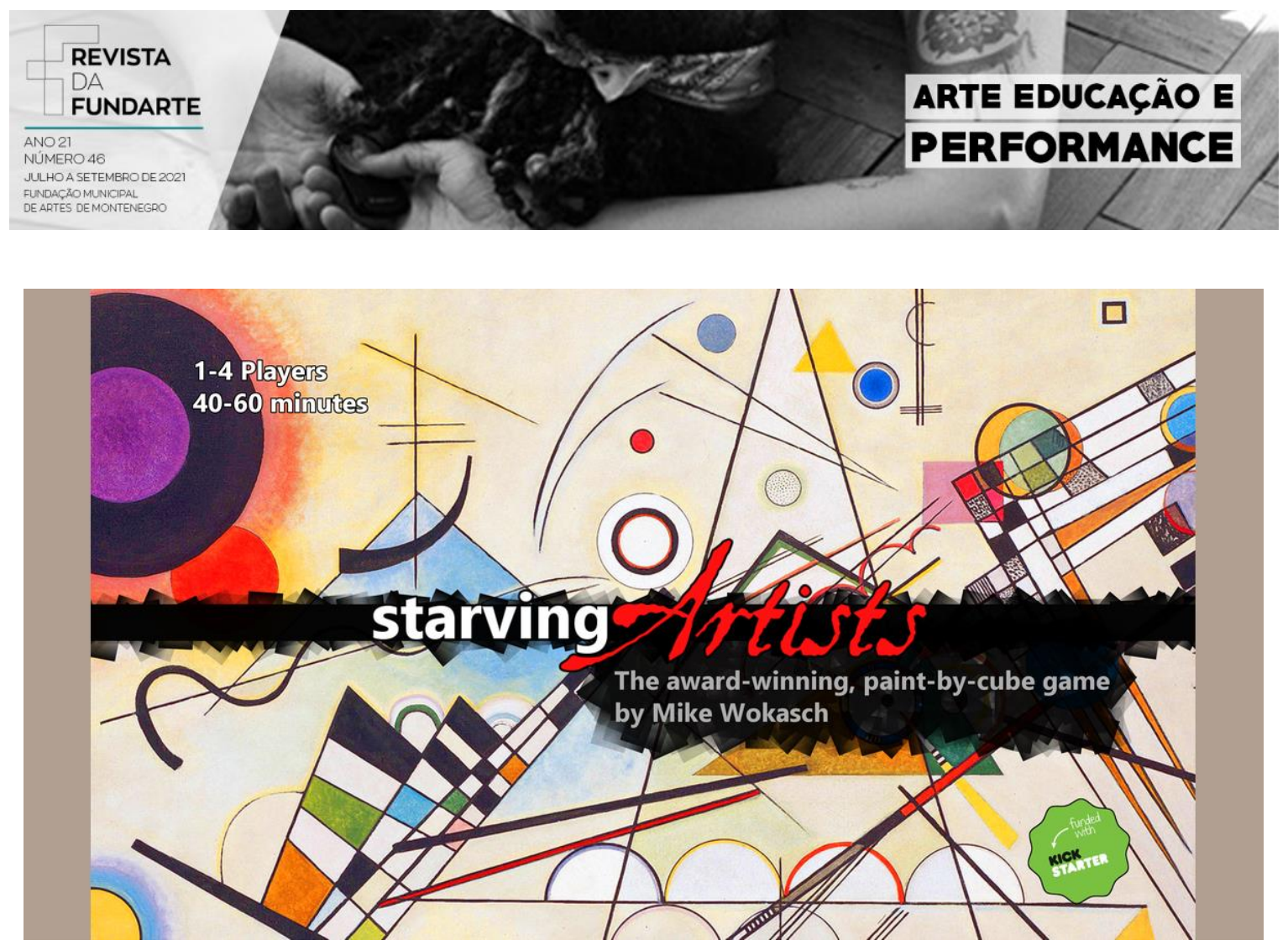

Figura 8: Starving Artists (Deep Water Games, 2017). Fonte: Boardgamegeek, 2020.

Outro exemplo do uso de componentes abstratos para representar o processo artístico é Sagrada (2017). O jogo é uma representação de criação de vitrais do Templo Expiatório da Sagrada Família em Barcelona utilizando dados coloridos de acrílico nas cores amarelo, azul, roxo, vermelho e verde. Além disso, o valor no dado representa a claridade ou obscuridade do tom da cor, isto é, quanto mais próximo do número 6 mais escura é a cor que ele representa. Os jogadores devem criar padrões coloridos seguindo a regra de que nunca podem ter dois dados da mesma cor ou do mesmo número um ao lado do outro.

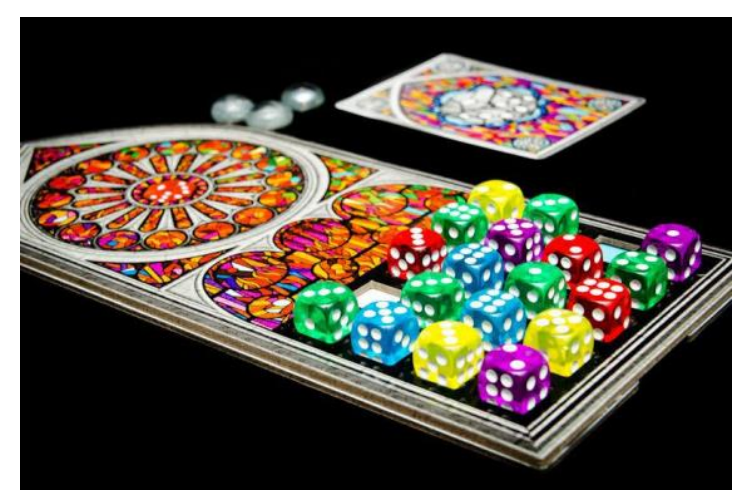

Figura 9: Sagrada (Floodgate Games, 2017). Fonte: Boardgamegeek, 2020.

CARMO, Raphael de Alcântara do; LIMA, José Maximiano Arruda Ximenes de. As influências da arte abstrata nos jogos de tabuleiros modernos. Revista da FUNDARTE. Montenegro, p.01-26, ano 21, no 46 , setembro de 2021.

Disponível em: http://seer.fundarte.rs.gov.br/index.php/RevistadaFundarte/issue/archive > 30 de setembro de 2021. 


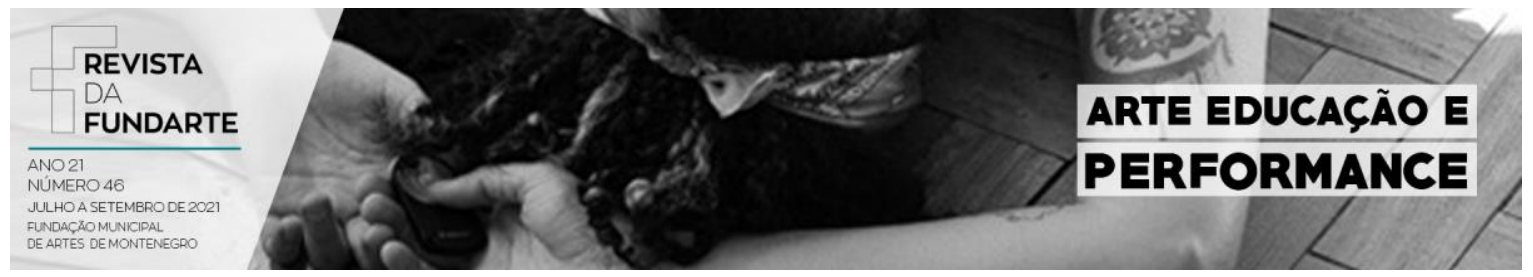

Aqui podemos perceber duas divisões geradoras de contraste discutidas por Kandinsky (2000, p. 31) no uso das cores. A primeira é o calor ou frieza do tom.

Cumpre-se entender por calor ou frieza de uma cor sua tendência geral para o amarelo ou para o azul. Essa distinção opera-se numa mesma superfície e a cor conserva seu tom fundamental. Esse tom torna-se mais material ou imaterial. Produz-se um movimento horizontal: o quente sobre essa superfície horizontal tende a aproximar-se do espectador, tende para ele, ao passo que o frio se distancia.

No jogo, podemos perceber a divisão entre cores quentes e frias de forma balanceada. $\mathrm{O}$ amarelo e o vermelho representam as cores quentes, o azul e o roxo representam as cores frias, e o verde é a cor central que fica no meio desse espectro.

O segundo elemento mecânico do jogo que faz um paralelo com os estudos de Kandinsky é o tom de obscuridade da cor.

O Segundo Contraste é constituído pela diferença entre o branco e o negro, cores que formam o segundo par dos quatro tons fundamentais pela tendência da cor para o claro e o escuro. Também aqui temos o movimento - em direção ao espectador e, em seguida, distanciando-se dele - anima o claro e o escuro. Movimento não mais dinâmico, mas estático e rígido .(KADINSKY, 2000, p. 32).

O jogo não se aprofunda muito nas questões de combinação de cores e tonalidades, orientando o jogador somente a evitar que números ou cores exatamente iguais fiquem adjacentes no seu vitral. Mas o jogo utiliza esses conceitos de combinação de cores e obscuridades para dar ao jogador decisões estratégicas e gerar resultados finais que se assemelham bastante aos vitrais do mundo real.

\section{CONSIDERAÇÕES FINAIS}

Mesmo que os conservadores ou até mesmo o indivíduo contemporâneo não nutram um apreço pela Arte Abstrata, é importante reconhecer o seu esforço e

CARMO, Raphael de Alcântara do; LIMA, José Maximiano Arruda Ximenes de. As influências da arte abstrata nos jogos de tabuleiros modernos. Revista da FUNDARTE. Montenegro, p.01-26, ano 21, no 46, setembro de 2021.

Disponível em: http://seer.fundarte.rs.gov.br/index.php/RevistadaFundarte/issue/archive > 30 de setembro de 2021 . 


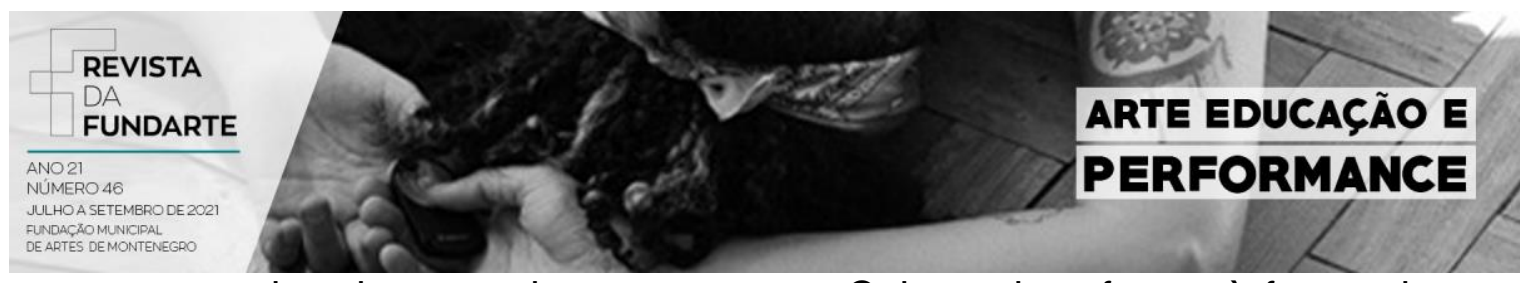

interesse em criar algo completamente novo. Colocando a forma à frente do tema, os pintores abstracionistas inspiraram toda uma geração de arquitetos e designers que usam suas obras como referências até hoje, seja para construir uma obra física ou uma interface digital.

Não é difícil relacionar os estudos de Kandinsky com alguns conceitos básicos do design gráfico, por exemplo. É notável que os conceitos de Abstracionismo tenham inspirado designers nas iconografias usadas em jogos de tabuleiro.

Apesar disso, dentre os jogos analisados, nenhum se propõe a falar sobre Arte Abstrata especificamente. Alguns deles utilizam obras artísticas abstratas representadas por cartas ou outros componentes de jogo, mas sem se aprofundar muito nas temáticas e técnicas. $\mathrm{O}$ jogo Starving Artists possui, inclusive, uma obra de Kandinsky na sua caixa de jogo, mas a decisão parece muito mais estética e de marketing do que algo pensado para representar a Arte Abstrata.

A abstração em jogos de tabuleiro, incluindo os jogos que falam sobre arte, acontece no processo mecânico de simular o mercado artístico ou no processo artístico com o uso de metáforas da temática traduzidas para mecânicas de jogo. Em nenhum desses jogos o jogador produz obras de arte da forma tradicional, usando pincéis ou mistura de pigmentos. O processo artístico é representado por ações estratégicas de gerenciamento de recursos para completar objetivos fixos préestabelecidos pelo jogo. Ou seja, o jogador não exercita sua liberdade ou criatividade no produto artístico final, mas sim nos meios em que ele vai buscar essa vitória, configurando um dos principais fatores de divertimento em um jogo de tabuleiro.

Os estudos da Arte Abstrata influenciaram designers a tomar decisões estéticas para representar os elementos dos jogos de forma mais simplificada e minimalista. Simples cubos coloridos de madeira podem representar guerreiros de fantasia, diferentes doenças ou o que mais o criador do jogo tiver em mente. Cabe à narrativa do jogo e à forma como elas se encaixam nas mecânicas para guiar a mente e a criatividade do jogador. Além disso, jogos que possuem as artes como abstrata nos jogos de tabuleiros modernos. Revista da FUNDARTE. Montenegro, p.01-26, ano 21, no 46, setembro de 2021.

Disponível em: http://seer.fundarte.rs.gov.br/index.php/RevistadaFundarte/issue/archive $>30$ de setembro de 2021. 


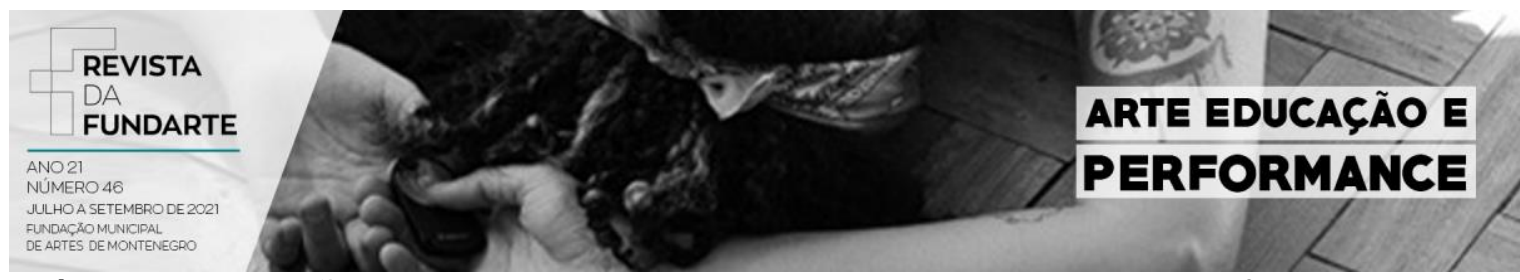

temática podem não pedir que o jogador produza obras de arte da forma tradicional como parte das suas regras, mas podem acabar influenciando para que ele pesquise e aprenda mais sobre esse assunto ao final da partida.

\section{Referências:}

Banco Imobiliário. São Paulo: GROW Jogos e Brinquedos, 1935. 1 jogo de tabuleiro.

Catan. Stuttgart: KOSMOS, 1995. 1 jogo de tabuleiro.

Colors of Paris. Paris: Super Meeple, 2019. 1 jogo de tabuleiro.

Cubist. Taipé: Bright World Games, 2014. 1 jogo de tabuleiro.

DAVIAU, Rob. Design Intuitively. In: SELINKER, Mike. The Kobold Guide to Board Game Design. New York: Open Design LLC, 2012. p. 56-66.

Dungeons and Dragons. Renton: Wizards of the Coast, 1975. 1 jogo de RPG.

FORBECK, Matt. Metaphor vs. Mechanics. In: SELINKER, Mike. The Kobold Guide to Board Game Design. New York: Open Design LLC, 2012. p. 56-66.

GOMBRICH, F. H. A História da Arte. 16. ed. São Paulo: LTC. 2010.

GOMES, Silvia Trentim. Jogo de cartas adaptável e contextualizável para a interpretação de imagens no Ensino de Artes Visuais. Tese (Tecnologias da Inteligência e Design Digital) - Pontifícia Universidade Católica de São Paulo. São Paulo. 2019.

JANSON, H. W; JANSON, Antony E. Iniciação à História da Arte. Rio de Janeiro: Martins Fontes, 1988.

JULL, Jesper: A Certain Level of Abstraction. In: DIGRA '07 - PROCEEDINGS OF THE 2007 DIGRA INTERNATIONAL CONFERENCE: SITUATED PLAY, 7., 2007, Tokyo. Anais... Tokyo: DiGRA Japan, 2007, p. 510-515.

KANDINSKY, Wassily. Akhtyrka - Outono. 1901. Pintura, óleo sobre tela, $24.0 \times$ $33.0 \mathrm{~cm}$.

. Composição VIII. 1923. Pintura, óleo sobre tela, 140.0 × $201.0 \mathrm{~cm}$.

. Do Espiritual na Arte. 3 ed. São Paulo: Martins Fontes, 2000.

CARMO, Raphael de Alcântara do; LIMA, José Maximiano Arruda Ximenes de. As influências da arte abstrata nos jogos de tabuleiros modernos. Revista da FUNDARTE. Montenegro, p.01-26, ano 21, no 46, setembro de 2021.

Disponível em: http://seer.fundarte.rs.gov.br/index.php/RevistadaFundarte/issue/archive $>30$ de setembro de 2021. 


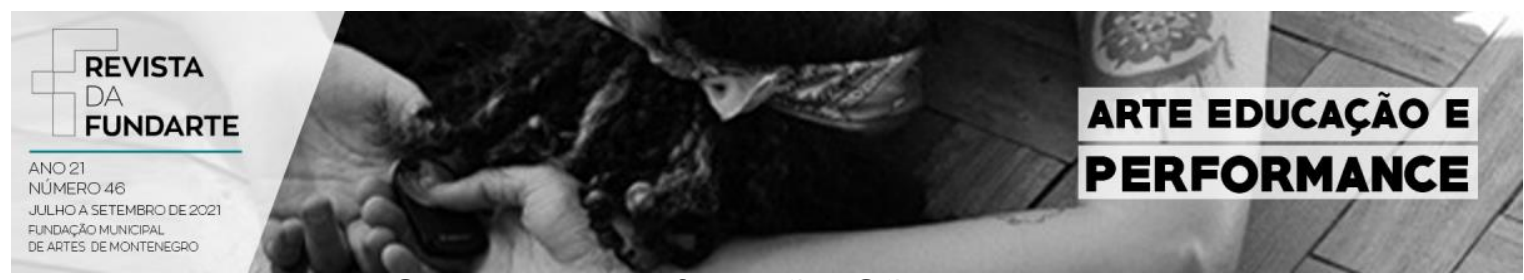

. Ponto e Linha Sobre Plano. 2 a Edição. São Paulo: Martins Fontes, 2012.

LAMBERT, Rosemary. A Arte do Século XX. Rio de Janeiro: Zahar, 1984.

Lords of Waterdeep. Renton: Wizards of the Coast, 2012. 1 jogo de tabuleiro.

Magic: The Gathering. Renton: Wizards of the Coast,1993. 1 jogo de cartas.

Modern Art. Munique: Hans im Glück, 1992. 1 jogo de tabuleiro.

MONDRIAN, Piet. 1929. Pintura, óleo e papel em tela, $59,5 \mathrm{~cm} \times 59,5 \mathrm{~cm}$.

NUNES, Benedito. Introdução à filosofia da arte. 5. ed. São Paulo: Ática, 2005.

Pandemic. Nova Yorke: Z-Man Games, 2008. Jogo de tabuleiro.

PARLETT, David. The Oxford Dictionary of Boardgames. Oxford: Oxford University Press, 1992.

PESQUISA GAMES BRASIL. Pesquisa Games Brasil 2019. Disponível em: <http:// https://materiais.pesquisagamebrasil.com.br/painel-gratuito-2019. Acesso em: 20 ago. 2020.

PROENÇA, Graça. História da Arte. São Paulo: Ática, 2012.

ROSA, Gabriel. VARGAS, Antônio. Game abstrato: considerações sobre as relações entre games digitais e arte abstrata. DAPesquisa, v.10, n.14, p38-52, novembro 2015.

Sagrada. Minneapolis: Floodgate Games, 2017. 1 jogo de tabuleiro.

Starving Artists. Saginaw: Deep Water Games, 2017. 1 jogo de tabuleiro.

The Gallerist. Leitchfield: Eagle-Gryphon games, 2015. 1 jogo de tabuleiro.

Twilight Imperium: Quarta Edição. Roseville: Fantasy Flight Games, 2017. 1 jogo de tabuleiro.

War. São Paulo: GROW Jogos e Brinquedos, 1975. 1 jogo de tabuleiro.

WOODS, Stewart. Eurogames: The Design, Culture and Play of Modern European Board Games: 1 ed. Carolina do Norte: McFarland. 2012.

WORRINGER, Wilhelm. Problemática Del Arte Contemporâneo. Buenos Aires: Nueva Vision, 1958. 